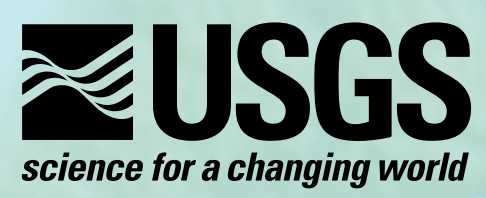

\title{
Revision of Time-Independent Probabilistic Seismic Hazard Maps for Alaska
}

Open-File Report 2007-1043 


\section{Revision of Time-Independent Probabilistic Seismic Hazard Maps for Alaska}

By Robert L. Wesson, Oliver S. Boyd, Charles S. Mueller, Charles G. Bufe, Arthur D. Frankel, and Mark D. Petersen

Open-File Report 2007-1043 


\title{
U.S. Department of the Interior DIRK KEMPTHORNE, Secretary
}

\author{
U.S. Geological Survey \\ Mark D. Myers, Director
}

\section{U.S. Geological Survey, Reston, Virginia: 2007}

For product and ordering information:

World Wide Web: http://www.usgs.gov/pubprod

Telephone: 1-888-ASK-USGS

For more information on the USGS—-the Federal source for science about the Earth, its natural and living resources, natural hazards, and the environment:

World Wide Web: http://www.usgs.gov

Telephone: 1-888-ASK-USGS

Any use of trade, product, or firm names is for descriptive purposes only and does not imply endorsement by the U.S. Government.

Although this report is in the public domain, permission must be secured from the individual copyright owners to reproduce any copyrighted materials contained within this report.

Suggested citation:

Wesson, Robert L., Boyd, Oliver S., Mueller, Charles S., Bufe, Charles G., Frankel, Arthur D., Petersen, Mark D., 2007, Revision of time-Independent probabilistic seismic hazard maps for Alaska: U.S. Geological Survey Open-File Report 2007-1043. 


\section{Contents}

Abstract
Introduction
Geologic and Seismologic Setting
Methodology
Hazard Model
Smoothed Seismicity
Megathrust Sources

\section{Figures}

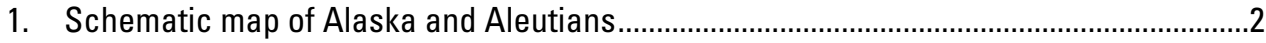

2. Instrumental seismicity of Alaska and the Aleutian Islands from the declustered consolidated catalog 
3. Rupture areas of large earthquakes in Alaska and the Aleutian Islands from 1900 to 2004.

4. Centroid moment tensors from Harvard catalog for events with $\mathrm{M}_{0} \cdot 5 \times 10^{25}$ dyne-cm for the period 1977-2004

5. Hazard Model for Alaska and Aleutians. ....................................................................

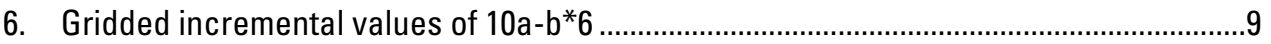

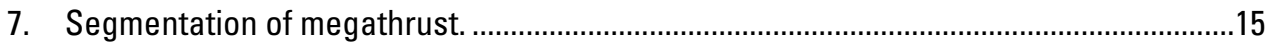

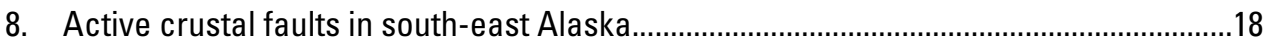

9. Active crustal faults in south-central Alaska...............................................................19

10. Probabilistic ground motion with a 2-percent probability of exceedance in 50 years for peak ground acceleration.

11. Probabilistic ground motion with a 10-percent probability of exceedance in 50 years for peak ground acceleration

12. Probabilistic ground motion with a 2-percent probability of exceedance in 50 years for peak ground acceleration at a larger scale in the Aleutians.

13. Percentage changes in the 2007 map relative to the 1999 map for south-central Alaska.

\section{Tables}

1. Characteristics of active faults assumed for hazard analysis.

2. Attenuation relationships assumed for various seismic sources ..................................22

3. Input files, key parameters, and hazard codes used in preparing the maps ....................23

4. Selected ground-motion values and percentage changes from the 1999 map at representative cities and towns in Alaska and the Aleutians.

\section{Conversion Factors}

\section{SI to Inch/Pound}

\begin{tabular}{lcl}
\hline Multiply & By & To obtain \\
\hline & Length & \\
\hline centimeter (cm) & 0.3937 & inch (in.) \\
millimeter (mm) & 0.03937 & inch (in.) \\
meter (m) & 3.281 & foot (ft) \\
kilometer $(\mathrm{km})$ & 0.6214 & mile (mi) \\
meter $(\mathrm{m})$ & 1.094 & yard (yd) \\
\hline
\end{tabular}




\title{
Revision of Time-Independent Probabilistic Seismic Hazard Maps for Alaska
}

\author{
By Robert L. Wesson, Oliver S. Boyd, Charles S. Mueller, Charles G. Bufe, Arthur D. Frankel, and \\ Mark D. Petersen
}

\section{Abstract}

We present here time-independent probabilistic seismic hazard maps of Alaska and the Aleutians for peak ground acceleration (PGA) and 0.1, 0.2, 0.3, 0.5, 1.0 and 2.0 second spectral acceleration at probability levels of 2 percent in 50 years (annual probability of 0.000404 ), 5 percent in 50 years (annual probability of 0.001026) and 10percent in 50 years (annual probability of 0.0021). These maps represent a revision of existing maps based on newly obtained data and assumptions reflecting best current judgments about methodology and approach. These maps have been prepared following the procedures and assumptions made in the preparation of the 2002 National Seismic Hazard Maps for the lower 48 States. A significant improvement relative to the 2002 methodology is the ability to include variable slip rate along a fault where appropriate. These maps incorporate new data, the responses to comments received at workshops held in Fairbanks and Anchorage, Alaska, in May, 2005, and comments received after draft maps were posted on the National Seismic Hazard Mapping Web Site. These maps will be proposed for adoption in future revisions to the International Building Code. In this documentation we describe the maps and in particular explain and justify changes that have been made relative to the 1999 maps.

We are also preparing a series of experimental maps of time-dependent hazard that will be described in future documents.

\section{Introduction}

Probabilistic seismic hazard maps for Alaska and the Aleutians were prepared in 1985 (Thenhaus and others, 1985) and 1999 (Wesson and others, 1999a 1999b). The aim of the present effort is to revise and extend the previous maps taking into account new and improved information about the earthquake hazard in the region and improvements in methodology. The most significant development since the preparation of the 1999 maps was the occurrence of the November 3, 2002, Denali earthquake (Mw 7.9), which was accompanied by thrust and right-lateral strike-slip surface fault ruptures extending $340 \mathrm{~km}$ along the Susitna Glacier, central Denali, and Totschunda faults, reaching a maximum of about $8 \mathrm{~m}$ (Eberhard-Phillips and others, 2003; Crone and others, 2004; Haeussler and others, 2004). The earthquake led to a significant geologic effort (Schwartz and others, 2005a and b; Matmon, 2006) that will result in a vastly improved understanding of both the long-term slip rates on these faults and the earthquake history extending back about 2,000 years. These efforts have led to improved estimates of slip rates on the Denali and Totschunda faults. (Selected faults and geographic locations are shown in figure 1). New paleoseismic data are also available for the Castle Mountain fault, which, after the Alaska-Aleutian megathrust zone, appears to be the most significant threat to the most heavily populated part of Alaska near Anchorage (Haeussler and others, 2002). New geologic information has also been obtained on Quaternary faults exposed on Kodiak Island (Carver and others, 2003), and slightly revised slip rates are available for the Fairweather-Queen Charlotte fault system and the Transition fault (DeMets and Dixon, 1999; Freymueller and Fletcher, 1999; Fletcher and Freymueller, 2003). In addition, earthquake catalogs have been extended, and improved earthquake locations and new geophysical studies have contributed to improved understanding of the geometry of the megathrust zone and hazard in the Cook Inlet region (Doser and others, 2004; Haeussler and others, 2000; Ratchkovski and Hansen, 2002b). Methodological improvements underlying these maps, relative to 1999, principally following the 2002 National Map, include the explicit inclusion of epistemic uncertainty, new attenuation relationships, and log-log interpolation (rather than log-linear interpolation) of probabilistic ground-motion values between the directly calculated values. Improvements specific to the Alaska maps include improved characterization of the subduction zone and minor improvements in the approach to the calculation of parameters representing smoothed seismicity. We also consider the partial seismic decoupling along the Transition fault (fig. 1). The ability to calculate probabilistic ground motion assuming a spatially variable slip rate on a fault enables us to capture more realistically the hazard along the southeastern Denali fault and in a few other areas. These changes will be discussed in detail herein. 


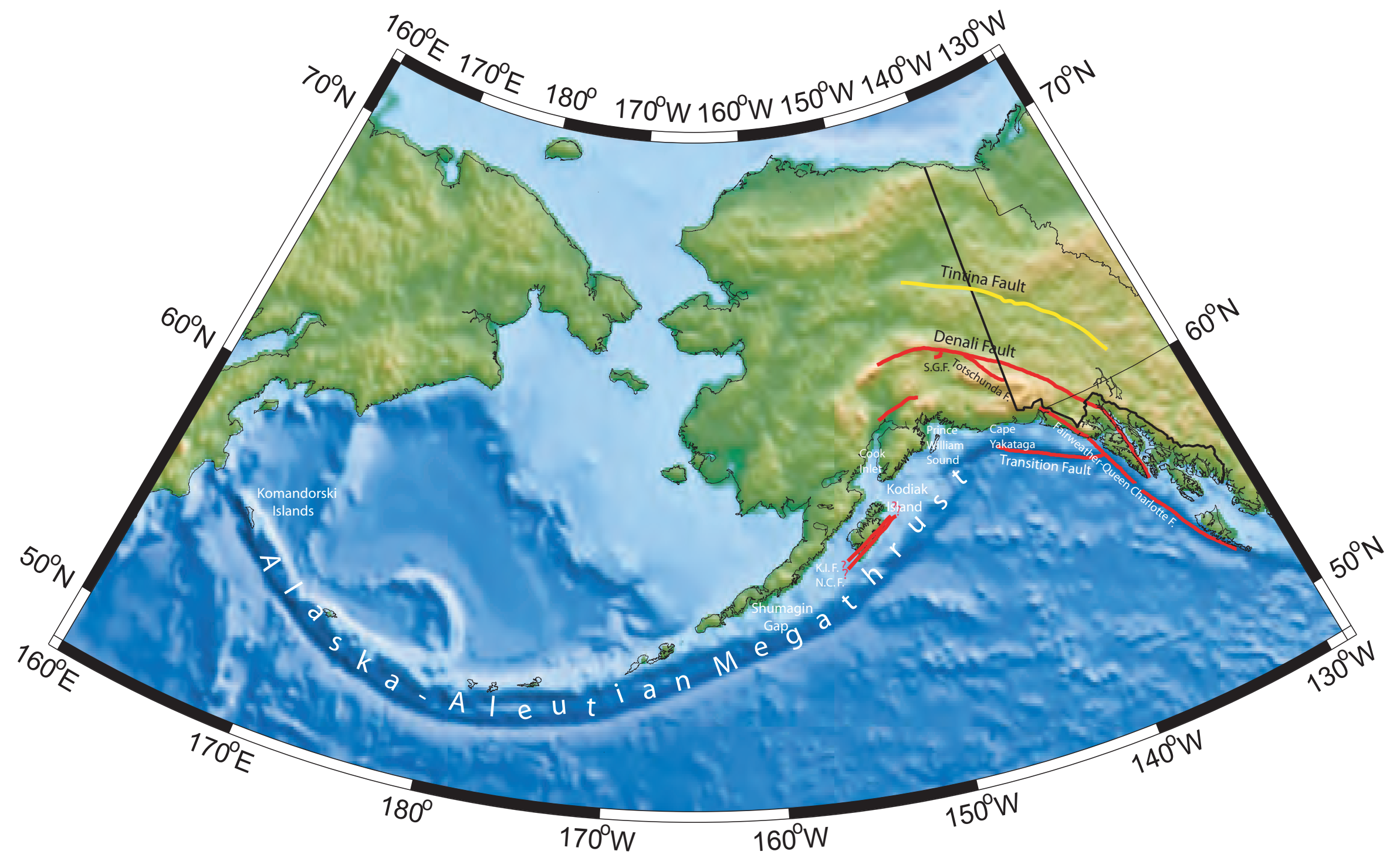

Figure 1. Schematic map of Alaska and Aleutians showing selected crustal faults used in calculation of seismic hazards (shown in red) and geographic features referred to in text. Neither the Tintina fault (shown in yellow) nor the Susitna Glacier fault (denoted by "S.G.F.") are explicitly included in the hazard map. The Kodiak Island and Narrow Cape faults are denoted by "K.I. F." and "N.C. F.", respectively. The offshore extent of these faults is poorly understood. 
To gather new data and to provide an opportunity for discussion among experts on these issues, two workshops were held in Alaska in May 2005, and one meeting with Canadian colleagues was held in June 2005. Additional comments were obtained in response to the posting of draft maps on the National Seismic Hazard Mapping Web Site during the fall of 2005.

\section{Geologic and Seismologic Setting}

Alaska is the most seismically active State in the United States. The 1964 Prince William Sound earthquake (Mw 9.2) is one of the three largest earthquakes to occur since the beginning of instrumental recording in the late 1800s. (The other two are the 1960 Chilean earthquake and the 2004 SumatraAndaman Islands earthquake.) The 2002 Denali fault earthquake ( $\mathrm{Mw}$ 7.9) is the largest onshore earthquake to strike the United States since the San Francisco earthquake of 1906. Although the population of Alaska remains small, the potential for very significant impacts on important natural-resource production and transportation facilities, on critical military facilities, and on the more populated regions of the State from a large earthquake must be taken very seriously. Fortunately, the 2002 earthquake occurred in a sparsely populated region of the State, and the impact was relatively modest. The Denali fault earthquake was accompanied by fault rupture over a distance of $340 \mathrm{~km}$, with offsets up to $8 \mathrm{~m}$. Although the Trans-Alaska Pipeline was offset about $5 \mathrm{~m}$, the pipeline survived the event owing to careful engineering and preparation for fault rupture and ground-shaking hazard (Cluff and others, 2003; Hall and others, 2003) preventing untold economic losses and environmental damage.

The instrumental seismicity of Alaska and the Aleutians for earthquakes since 1900 greater than or equal to magnitude 5.5 is shown in figure 2. Clearly, most of the seismicity in the region is associated with the Alaska-Aleutian megathrust fault extending eastward along the Aleutian arc into south-central Alaska. The northwestward-moving Pacific plate is subducted along this megathrust beneath the North American plate, giving rise to the Aleutian trench, islands, and related volcanic activity. Additional significant seismicity occurs along the Denali fault in south-central Alaska and along a northwestward-striking system of right-lateral strike-slip faults extending southeastward through and offshore from the panhandle of southeast Alaska (Page and others, 1991). The southeastern portion of this system of faults forms the northeast boundary of the Pacific plate. Additional seismicity also occurs elsewhere in central Alaska.

The estimated rupture zones of the largest earthquakes in this century are shown in figure 3 (Plafker and others, 1993; Ratchkovski and others, 2004). During this century, virtually the entire plate boundary from the westernmost Aleutian Islands to the Queen Charlotte Islands off British Columbia has ruptured in large to great earthquakes. The only exceptions are areas near the Komandorski Islands, near the Shumagin Islands, and near Cape Yakataga (Sykes, 1971; Davies and others, 1981). Near the Komandorski Islands, historical records of large earthquakes in 1849 and 1858 at the extreme western end of the arc have been judged as insufficient to conclude that plate-margin-rupturing earthquakes have occurred there (Sykes and others, 1981; Taber and others, 1991). At this location, subduction is occurring at a highly oblique angle, and it has been argued that the recurrence properties of large earthquakes here may differ significantly from those elsewhere along the arc. Indeed, Cormier (1975) has argued that the region may be incapable of supporting a great earthquake, although in light of the 2004 Sumatra-Andaman Islands earthquake, this interpretation must be revisited. In the vicinity of the Shumagin Islands, that is, in the region between the 1957 and 1938 earthquakes, it has been argued that no great earthquake has occurred in this century. Similarly, the vicinity of Cape Yakataga has experienced no great earthquakes since 1899 or before. These two regions have been identified as "seismic gaps"- that is, the potential sites of future large earthquakes (Sykes, 1971; Lahr and others, 1980; Davies and others, 1981). Although concern remains about the possibility of a large earthquake in the Yakataga region, recent analysis of GPS geodetic measurements in the Shumagin Islands suggests that very little strain is currently accumulating there and that slip along the megathrust may be accommodated aseismically (Freymueller and Beavan, 1999).

The broad scale stress system causing earthquakes in Alaska and the Aleutians can be seen in figure 4 in which are plotted the centroid moment tensors from the Harvard catalog (http://www.globalcmt.org/CMTsearch.html) for significant earthquakes since 1977 together with motion vectors for the Pacific plate relative to the North American plate from NUVEL 1-A (DeMets and others, 1994). Evident in figure 4 is the gradual transition from perpendicular subduction in the Prince William Sound and eastern Aleutian regions to the oblique subduction in the far western Aleutian and Komandorski Island region.

\section{Methodology}

The overall methodology used in the preparation of these maps is the same used in the previous Alaska map (Wesson and others, 1999a, 1999b) and in the 1996 and 2002 probabilistic seismic hazard maps for the contiguous 48 States (Frankel and others, 1996, 2002) based on the basic approach of Cornell (1968). The methodology combines estimates of the frequencies and magnitudes of earthquakes from potential sources with empirical relationships for the attenuation of strong ground motion with distance from the source to make a quantitative estimate of the ground motion at each point on the map for various probability levels, for example, the ground motion with a 2-percent probability of exceedance in 50 years. 


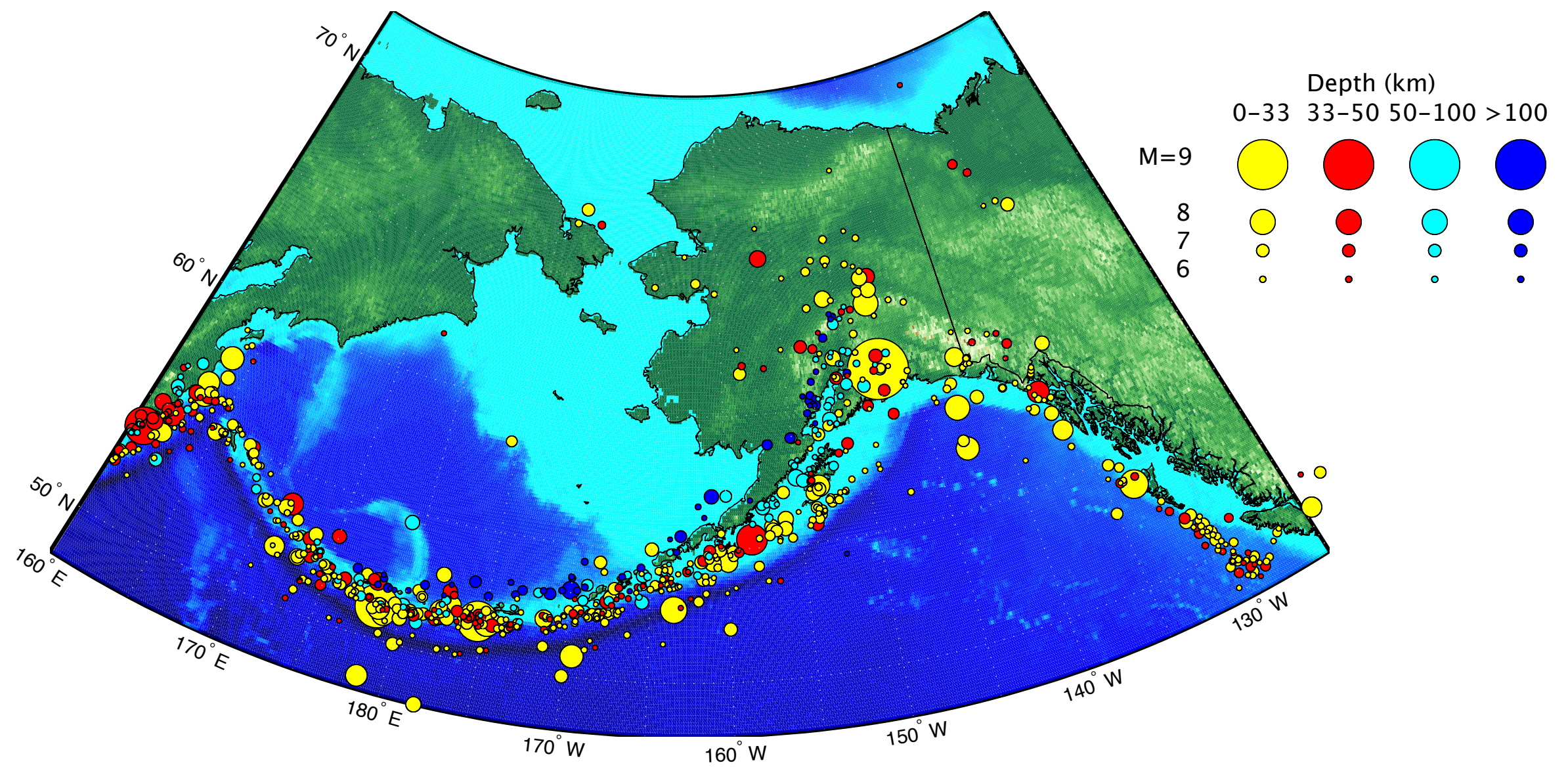

Figure 2. Instrumental seismicity of Alaska and the Aleutian Islands from the declustered consolidated catalog. Earthquakes shown have magnitudes Mw•5.5 and dates ranging from 1990 to 2004. 


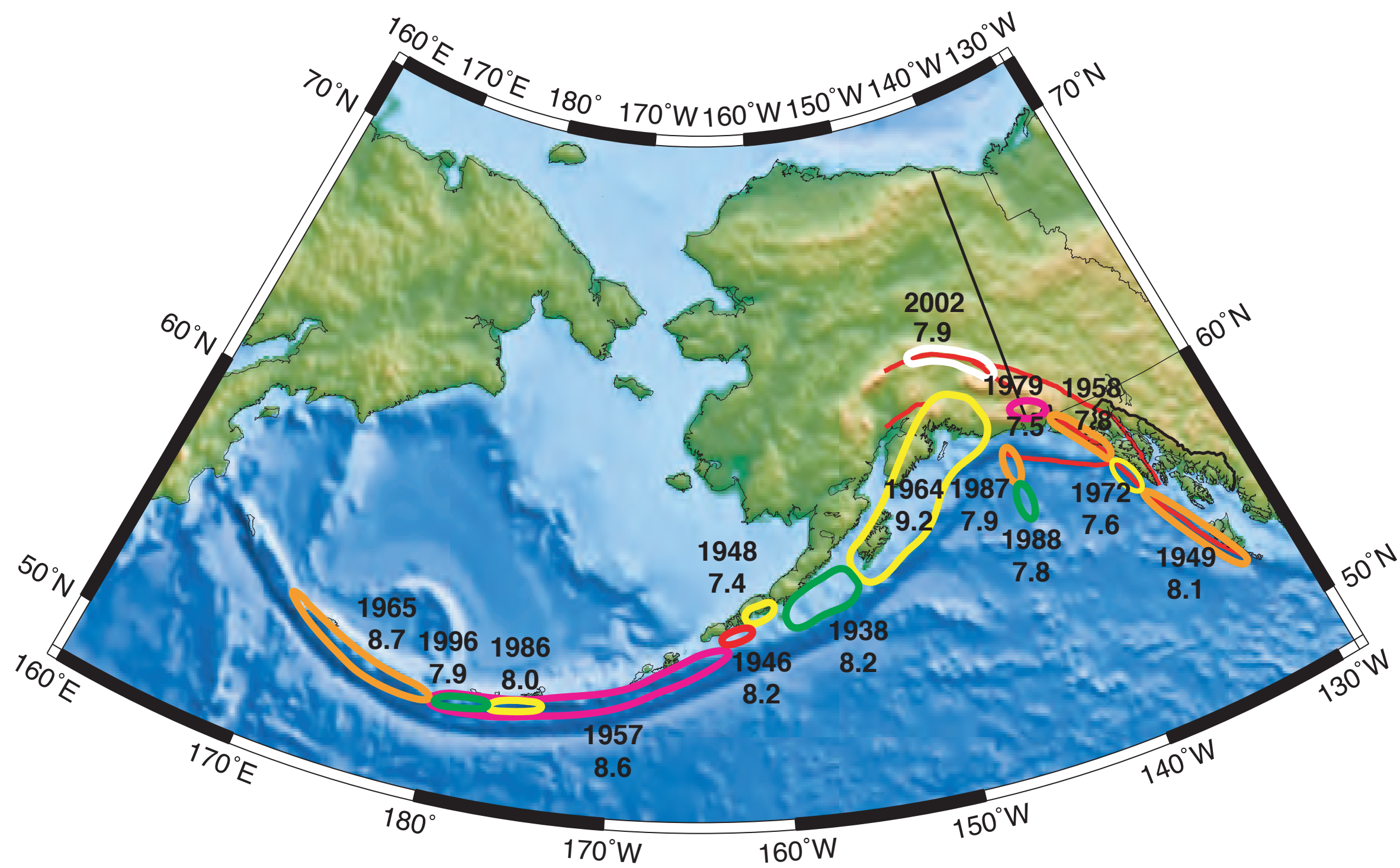

Figure 3. Rupture areas of large earthquakes in Alaska and the Aleutian Islands from 1900 to 2004. 


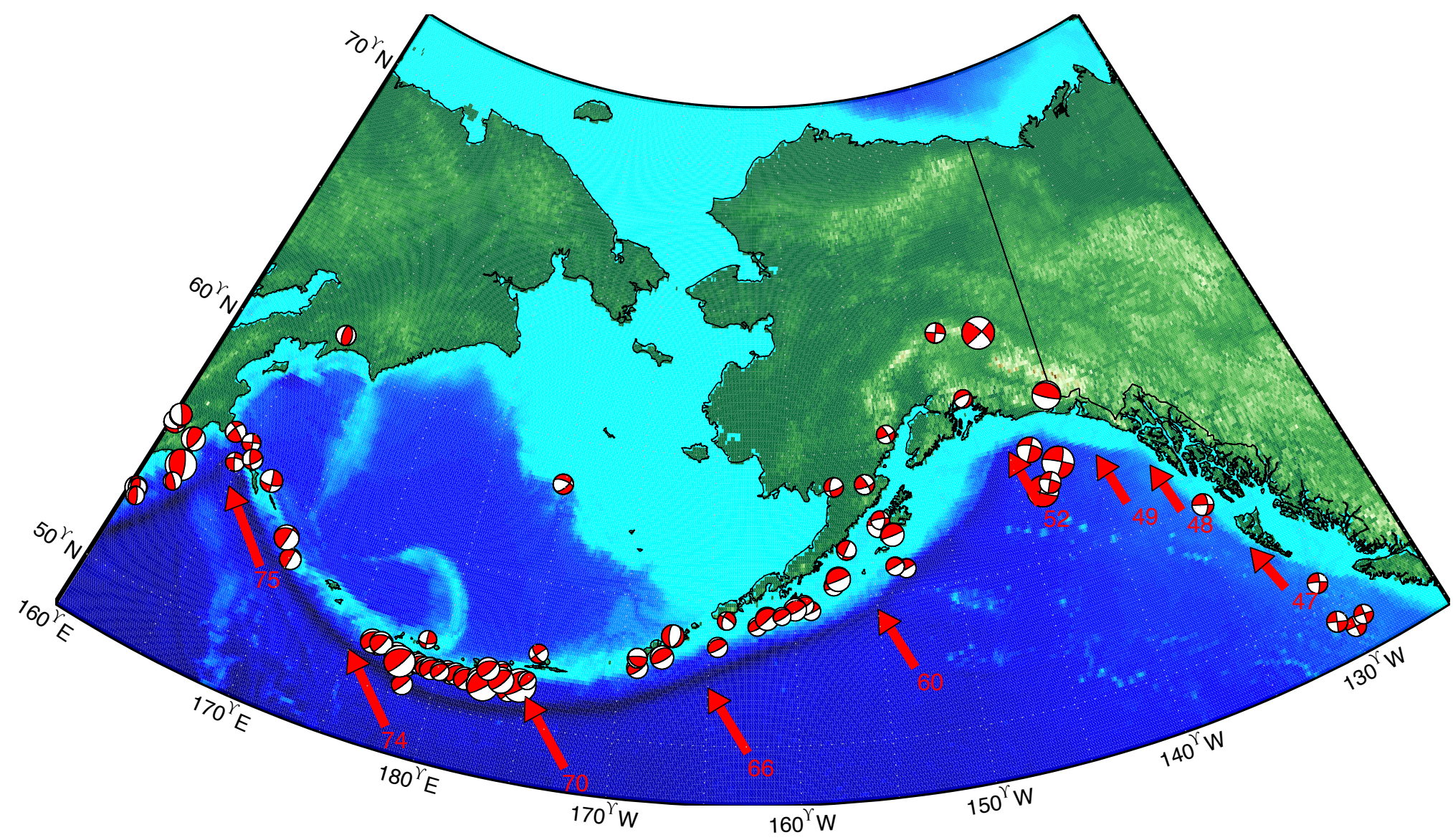

Figure 4. Centroid moment tensors from Harvard catalog for events with $\mathrm{M}_{0} \cdot 5 \times 10^{25}$ dyne-cm for the period 1977-2004. Also shown are plate motion vectors for the motion of the Pacific plate relative to North America from the NUVEL 1a model. Numbers indicate rates of plate motion in millimeters per year. Other plate motion models such as REVEL (Sella and others, 2002) show very similar results. 


\section{Hazard Model}

For purposes of preparing the hazard map, the potential sources of earthquakes in Alaska and the Aleutians are treated in three categories: (1) uncharacterized and unrecognized faults, which are represented by smoothed seismicity; (2) active faults with known parameters (that is, slip rate, recurrence interval, and so forth) recognized in the interior of Alaska and onshore and offshore regions of southeast Alaska; and (3) the Alaska-Aleutian megathrust associated with the subduction of the Pacific plate. Because the map makes a quantitative estimate of ground motion, each source included in the map must have some degree of quantitative information allowing estimation of the frequencies and sizes of earthquakes that it might generate.

The overall strategy for combining the hazards from these sources is summarized in figure 5 , to which we will make reference in the following sections. We now briefly review how each of the three source types is characterized and then discuss each of the source regions in more detail.

\section{Smoothed Seismicity}

An updated and revised catalog, including earthquakes in the time interval intervening since the 1999 maps, was prepared and used to calculate updated estimates of the smoothed seismicity. We combined catalogs from Engdahl and Villaseñor's International Association for Seismology and Physics of the Earth's Interior (IASPEI) project, Stover and Coffman's Seismicity of the United States, the U.S. Geological Survey Preliminary Determination of Epicenters (PDE), the International Seismological Centre (ISC), and the Alaska Earthquake Information Center (AEIC). A subjective ranking of source catalogs was made to select the best focal coordinates and moment magnitude for each event from 1898 through 2004. Listed moment magnitudes were preferred and used directly. Other magnitudes were converted to moment magnitude by using published relations (Utsu, 2002; Sipkin, 2003). Moment magnitude is referred to simply as magnitude in the following discussion. The catalog was declustered using the Gardner and Knopoff (1974) algorithm following the procedure used in the 1999 Alaska map and the 2002 map for the lower 48 States. For 12 of the largest mainshocks ${ }^{1}$ for which published aftershock studies were available, aftershocks were removed from the catalog within zones based on the published studies rather than the default circular zones specified by Gardner and Knopoff. (In the interest of transparency and reproducibility we chose the simpler Gardner and

\footnotetext{
${ }^{1}$ Aftershocks were removed based on zones defined in published studies for the following earthquakes and intervals: 19490822 Queen Charlotte (M8.1), 1,000 days; 19570309 Great Aleutian (M8.6), 1,500 days; 19580710 Fairweather (M7.7), 500 days; 19640328 Prince William Sound (M9.2), 1,500 days; 19650204 Rat Islands (M8.7), 1,300 days; 19720730 Sitka (M7.6), 500 days; 19790228 St. Elias (M7.5), 600 days; 19860507 Andreanof Island (M8.0), 1,000 days; 19871130 Gulf of Alaska (M7.9), 750 days; 19880306 Gulf of Alaska (M7.8), 750 days; 20021103 Denali fault (M7.9), 500 days.
}

Knopoff approach over methods that require the setting of tuning parameters to determine the clustering.) The 1898-2004 catalog with magnitude $\geq 4.0$ contained about 21,000 records. After declustering, about 7,500 mainshocks remained: about 450 from Engdahl and Villaseñor, about 220 from Stover \& Coffman, about 4,270 from PDE, about 2,070 from ISC, and about 500 from AEIC.

Overall completeness levels were determined from the catalog: magnitude $\geq 4.5$ since 1964 , magnitude $\geq 6.0$ since 1932 , and magnitude $\geq 6.9$ since 1898 . To model the smoothed seismicity, we assumed an exponential magnitude-frequency distribution,

$$
\log _{10} n=a-b M,
$$

where $n$ is the number of earthquakes per year in a magnitude interval, $\mathrm{M}$ is magnitude, and $a$ and $b$ are parameters, and used Weichert's (1980) method for estimating $a$ and $b$ values in catalogs with variable completeness levels. Earthquakes with depth $0-50 \mathrm{~km}$ and associated with the megathrust were treated separately, as described herein. The remaining earthquakes were considered in three groups: those with depth $0-50$ $\mathrm{km}$ not associated with the megathrust, those with depth 50-80 $\mathrm{km}$, and those with depth $80-120 \mathrm{~km}$. Earthquake activity rates were calculated in each cell of a $0.1^{\circ}$-long $\times 0.1^{\circ}$-lat grid and smoothed using a two-dimensional Gaussian function with correlation distance $g$ (Frankel, 1995): $b=0.816$ and $g=75$ $\mathrm{km}$ for earthquakes with depth $\geq 50 \mathrm{~km}$ not associated with the megathrust, $b=0.858$ and $g=50 \mathrm{~km}$ for earthquakes with depth $>50 \mathrm{~km}$ and $\geq 80 \mathrm{~km}$, and $b=1.007$ and $g=50 \mathrm{~km}$ for earthquakes with depth $>80 \mathrm{~km}$ and $\geq 120 \mathrm{~km}$. The megathrust was divided into several subzones, and $b$ values and average $a$ values were estimated for earthquakes with depth $\geq 50 \mathrm{~km}$ within each subzone. The subzone average seismicity rate was prorated into each grid cell, giving a uniform (rather than gridded and smoothed) spatial pattern. This approach is described in more detail in the section "Detailed Model of Megathrust."

These grids, shown in figure 6, are used to estimate the hazard for earthquakes not associated with known faults. As shown in figure 4, these grids are used (1) for earthquakes in the megathrust zones with depths less than $50 \mathrm{~km}$ and magnitudes up to 7.0, (2) for earthquakes not located in the megathrust zones with depths from 0 to $50 \mathrm{~km}$ and magnitudes up to 7.3 , and (3) for earthquakes deeper than $50 \mathrm{~km}$ and magnitudes up to 7.5 .

\section{Changes for 2007}

The new catalog has been extended from the 1996 through the end of 2004. Improvements since 1999 have been made both in the choice of source catalogs and in catalog processing, notably magnitude conversion and aftershock analysis for the largest mainshocks. Incorporation of the Engdahl and Villaseñor catalog, with many carefully relocated earthquakes, is a major improvement. The DNAG (Decade of North American Geology) source catalog was used in 1999 but is not included in the updated catalog. This change accounts 
$5.0 \leq \mathrm{M} \leq 7.0^{*}$

\section{Spatially Smoothed Seismicity}

Shallow earthquakes $(0-50 \mathrm{~km})$

$5.0 \leq \mathrm{M} \leq 7.0$

Deeper earthquakes $(50-80 \mathrm{~km})$

$5.0 \leq \mathrm{M} \leq 7.0$

Deepest earthquakes $(80-120 \mathrm{~km})$

$5.0 \leq \mathrm{M} \leq 7.0$

Megathrust sources

$5.0 \leq \mathrm{M} \leq 7.0$

${ }^{*}$ An upper limit of magnitude 7.3 was adopted to accommodate the possibility of a background earthquake of that magnitude.

Figure 5. Hazard Model for Alaska and Aleutians.
$\mathrm{M} \geq 7.0$

\section{Megathrust Zone}

$7.0 \leq \mathrm{M} \leq 8.0$

Equal likelihood throughout megathrust zone with rate determined from average of entire zone determined from instrumental seismicity.

\section{$M \geq 8.0$}

Rates and maximum magnitudes determined by segment. Equally weighted with characteristic for

Prince William Sound and Kodiak segments.

\section{Faults with "known" segmentation}

$$
\text { ("Type-A") }
$$

Characteristic model using slip rates and recurrence data to obtain recurrence of maximum earthquake.

\section{Faults with "unknown" segmentation} ("Type-B")

Equal weights on characteristic model and on truncated Gutenberg-Richter model 7.0 to maximum magnitude using slip rates and recurrence data to obtain recurrence of maximum earthquake. 
A

$10^{\mathrm{a}-\mathrm{b}^{\star} 6} / 100 \mathrm{~km}^{2} / \mathrm{yr}(\mathrm{i}, 0.1), \mathrm{d} \leq 50$ kilometers

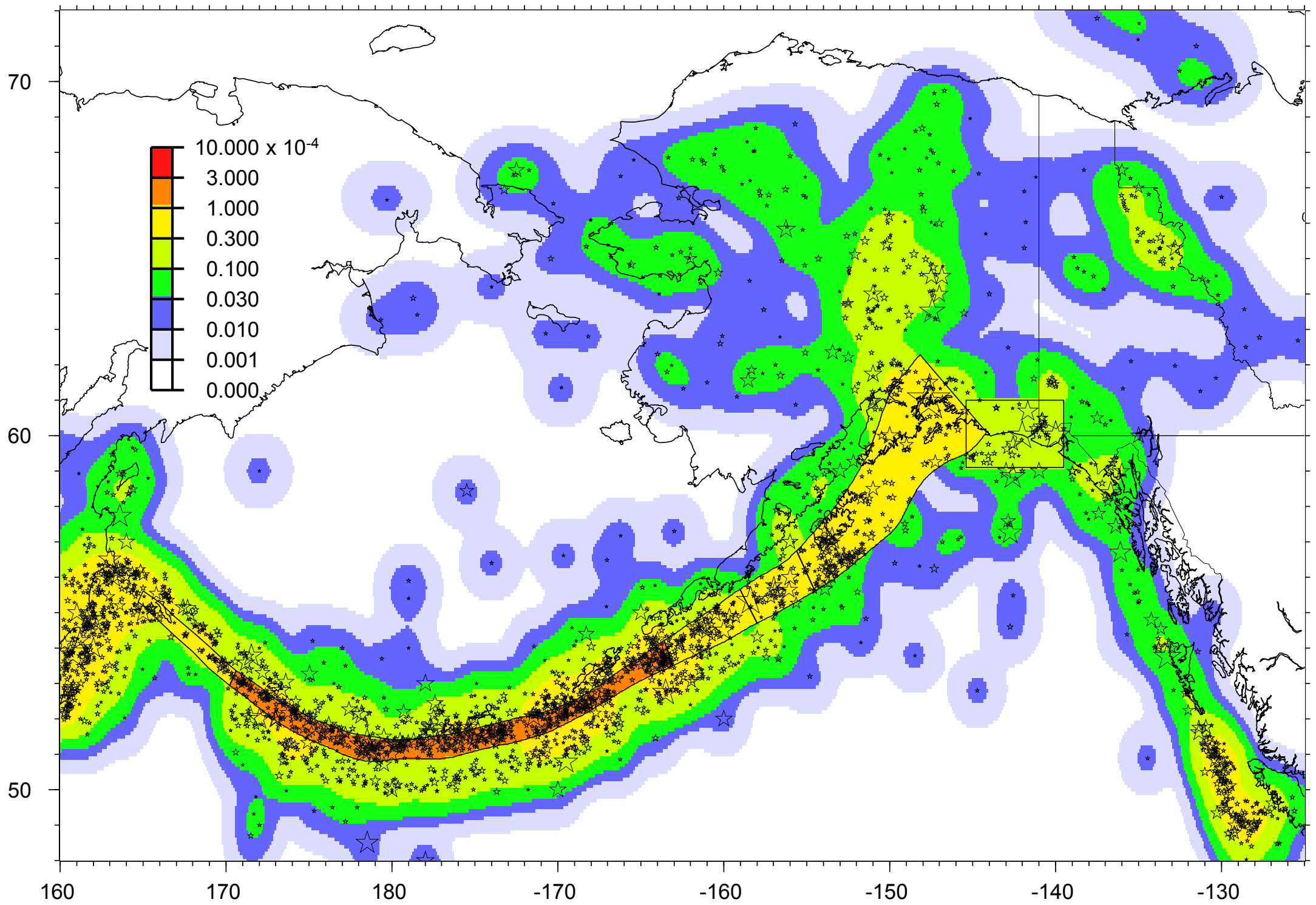

GMT Feb 28 08:10

Figure 6. Gridded incremental values of 10a-b*6 (the number of M6.0 earthquakes per 100 square kilometers per year) for $(A)$ earthquakes not associated with the megathrust with depths $0-50$ kilometers, $(B)$ earthquakes with depths $50-80$ kilometers and $(C)$ earthquakes with depths $80-120$ kilometers. 
B

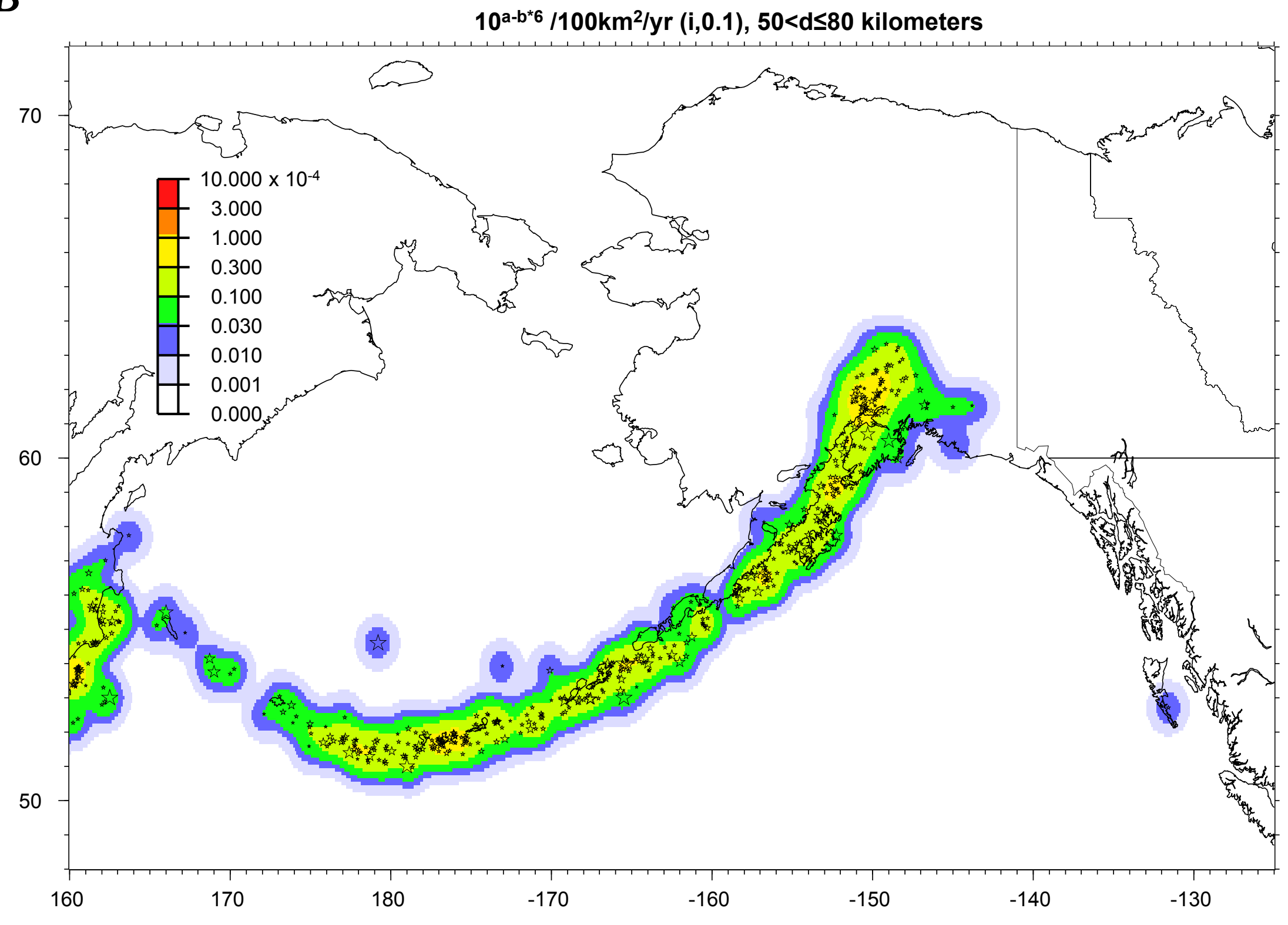




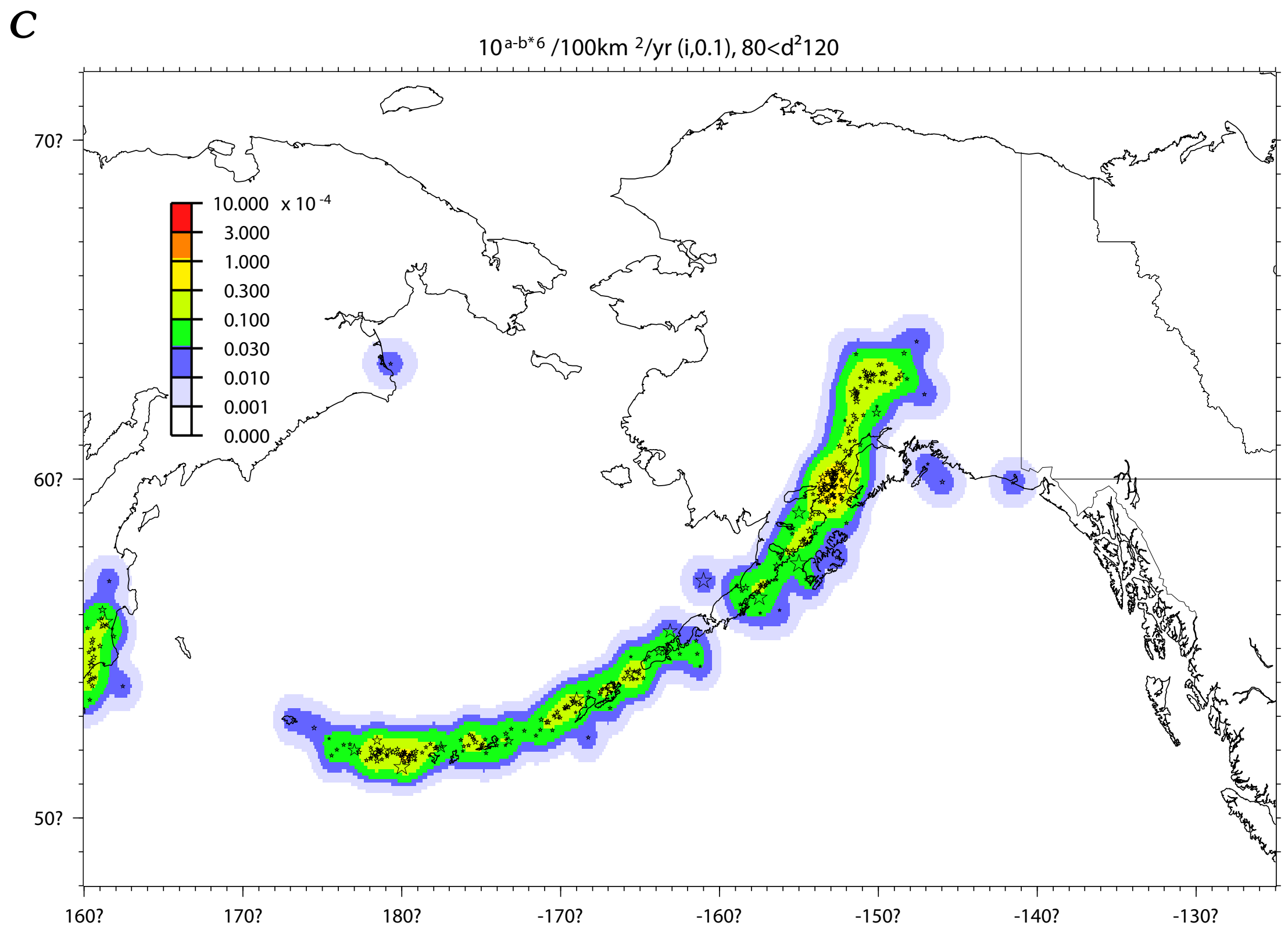

GMT Feb 28 08:10 
for some differences that are visible in low-hazard areas of the maps, where a single earthquake can make a clear difference. For example, two prominent hazard bull's-eyes (albeit at low levels of probabilistic ground motion) in the 1999 maps near $160^{\circ} \mathrm{W}$., $50^{\circ} \mathrm{N}$. in the Gulf of Alaska correspond to magnitude 4.5 and 4.8 earthquakes in 1982 from the DNAG catalog. These earthquakes are not listed in any other authoritative catalog, and the corresponding hazard disappears in the new maps.

\section{Fault Sources}

Information to characterize fault sources comes from a variety of types of studies. Ideally, one would like a long history of the origin times, magnitudes, rupture lengths, and displacements along each fault. Realistically, in the best cases, such as the preliminary results from the recent studies of the central Denali fault, we know the average slip rate over several thousand years and the approximate origin times of events at several discrete points along the fault. There is typically some uncertainty about the correlation of event times at adjacent and nearby sites. Event frequencies and size distributions are extracted from such data by variations of a strategy called "moment balancing." The moment of an earthquake is equal to the product of the area of slip times the average slip on that area times the elastic rigidity. The total moment released over an extended time, $T$, is equal to the product of the average slip rate on the fault, the time $T$, the area of the fault surface, and the elastic rigidity. Thus, from the slip rate and knowledge of the geometry of the fault, we know the sum of the moments of all the earthquakes, assuming that all the slip takes place during earthquakes. Incorporating the geologically measured long-term slip rate and whatever information is known about the timing and size of past earthquakes, together with generic models of the magnitude-frequency distribution of earthquakes on faults, we estimate the frequency of various magnitudes for each fault.

The generic models of the magnitude frequency distribution commonly used in USGS seismic hazard studies are the "characteristic" model, in which we assume that virtually all the seismic moment is released in repeated occurrences of similar earthquakes which are approximately the largest that can be expected for the fault, and the "truncated GutenbergRichter" model. It is well known that, over time, the earthquakes in a region follow a statistical relationship called the Gutenberg-Richter relation which states that the logarithm of the number of events in each magnitude interval is equal to a constant (the a-value) minus another constant (the b-value) times the magnitude. Typically, the b-value is near 1 , leading to the rule of thumb that one observes 10 times as many magnitude-six earthquakes as magnitude-seven earthquakes, and so forth. The application of the Gutenberg-Richter relation to a single fault, as opposed to a region, tends to estimate too many smaller earthquakes. A partial fix to this problem has been to use a truncated distribution considering only earthquakes between, say, magnitude 6.5 and some maximum magnitude. Commonly, this truncated distribution still predicts a higher ratio of lower magnitudes to higher magnitudes than is observed on a single fault. In contrast, the characteristic model, in its most simple application, predicts fewer earthquakes on a fault than are generally observed (see for example, Field and others, 1999; Frankel and others, 2002).

The approach taken in the preparation of past USGS hazard maps was to define two types of faults. The first, "Atype" faults, were assumed to be well characterized and to follow characteristic behavior. The second, "B-type" faults, were modeled with 50-percent characteristic behavior and 50percent truncated Gutenberg-Richter behavior. The properties of the faults characterized in the new map are summarized in table 1. A slight variation of this approach was taken for the Fairweather-Queen Charlotte fault system in 2007. In 1999 the fault segments were assumed to be characteristic and the segment boundaries were taken as fixed. It appears that the strongest evidence for these segment boundaries is the extent of the most recent earthquakes. Thus, in 2007, characteristic behavior on the segments was equally weighted with earthquakes in a truncated Gutenberg-Richter model in which the earthquakes are allowed to float without respect to segment boundaries. Hence, the Fairweather-Queen Charlotte fault system is no longer an "A-type" fault in the sense used previously, reducing the dependence of the resulting hazard calculations on the assumption of imperfectly known segment boundaries.

\section{Megathrust Sources}

Application of the moment-balancing strategy of estimating the frequency of earthquakes on the Alaska-Aleutian megathrust is not appropriate. Although the overall rate and direction of slip along the megathrust is well known-for example, about $5 \mathrm{~cm} /$ year approximately perpendicular to the fault in the region of Prince William Sound - a significant but poorly known fraction of the slip occurs without earthquakes. This is known as aseismic slip. The fraction of the total slip that is accommodated by aseismic slip also seems to vary with position along the megathrust. Over 3-5-year time periods, most if not virtually all the slip is accommodated by aseismic slip in the Shumagin Island region (Freymueller and Beavan, 1999) and almost no aseismic slip occurring in the Prince William Sound region (Cohen and Freymueller, 2004). There are also some indications that the amount of aseismic slip may vary with time (Buergmann and others, 2005). In short, means of estimating the frequency of large earthquakes along the megathrust must be found elsewhere.

For the eastern part of the megathrust, geologic studies within the delta of the Copper River by Plafker and Rubin (1994) and on the arms of Cook Inlet by Combellick (1994) and Bartsch-Winkler and Schmoll (1992) provide estimates of the origin times and frequencies of great earthquakes as reflected in subsidence in the sediments and peats. These estimates yield an average recurrence time of about 750 years for 1964-type events. Recent results with high-accuracy dating from the Girdwood area along Turnagain Arm of Cook Inlet 
Table 1. Characteristics of active faults assumed for hazard analysis.

\begin{tabular}{|c|c|c|c|c|}
\hline $\begin{array}{c}\text { Fault } \\
\text { (segment) }\end{array}$ & $\begin{array}{l}\mathrm{M}_{\text {char }} \\
\left(\mathrm{M}_{\max }\right)\end{array}$ & $\begin{array}{l}\text { Slip rate } \\
(\mathrm{mm} / \mathrm{yr})\end{array}$ & $\begin{array}{l}\text { Recurrence time }{ }^{1} \text { for } \\
\text { characteristic } \\
\text { earthquake } \\
\text { (years) }\end{array}$ & References \\
\hline Queen Charlotte & $8.1^{\mathrm{b}}$ & 49 & 155 & 1 \\
\hline $\begin{array}{l}\text { Fairweather, } \\
\text { offshore }\end{array}$ & $7.7^{\mathrm{b}}$ & 49.5 & 100 & 1 \\
\hline $\begin{array}{l}\text { Fairweather, } \\
\text { onshore }\end{array}$ & $8.0^{b}$ & 48 & 150 & 1 \\
\hline Denali, southeast & 7.9 & $8.4-2$ & $1,065-4,465$ & 2 \\
\hline $\begin{array}{l}\text { Denali, } \\
\text { central }\end{array}$ & 7.9 & $1-9.4-14.4$ & $\begin{array}{l}15,305-1,630-1,065^{\mathrm{c}} \\
21,430-2,280-1,490^{\mathrm{d}}\end{array}$ & 2 \\
\hline Totschunda & 7.9 & 6 & 1,490 & 2 \\
\hline Castle Mountain & 7.1 & $0.5-2.9-0.5$ & $4,255-730-4,255$ & 3 \\
\hline Transition & $8.2^{b}$ & 6 & 325 & (see text) \\
\hline Kodiak Island & 7.5 & 1 & 4,435 & 4 \\
\hline Narrow Cape & 7.5 & 2 & 2,220 & 4 \\
\hline
\end{tabular}

References

${ }^{1}$ DeMets and Dixon (1999); Fletcher and Freymueller (2003)

${ }^{2}$ Schwartz and others (2005a, 2005b)

${ }^{3}$ Willis and others (in press)

${ }^{4}$ Carver and others (2003)

Notes

aRecurrence times are estimated from the rate of seismic moment release for earthquakes of the characteristic magnitude required to balance the observed geologic slip rate. They represent recurrence within any section of fault length equal to Wells and Coppersmith (1994) surface rupture length. Ranges in recurrence time correspond to the ranges in slip rate along the fault.

bCharacteristic magnitudes estimated from fault length using the Wells and Coppersmith (1994)

relations.

cRecurrence times for ruptures on the Central Denali-Eastern Denali system.

${ }^{d}$ Recurrence times for ruptures on the Central Denali-Totschunda system. 
(Hamilton and Shennan, 2005; Hamilton and others, 2005; Shennan and Hamilton, 2006) indicate six great earthquakes in a period of 3,300 years for an average recurrence time of about 650 years. This value is adopted here.

The Kodiak Island region of the megathrust ruptured during the 1964 earthquake and is inferred to have also ruptured in previous 1964-type earthquakes. Based both on historical records (see for example, Nishenko and Jacob, 1990) and geologic evidence (Carver and others, 2003; Sauber and others, in press), this region has also been the locus of more frequent ruptures.

The western Aleutians display recurrence behavior that is decidedly not "characteristic," as will be discussed in more detail herein.

To model the behavior of the megathrust, we generally followed the approach used in 1999 of combining models for the characteristic behavior on the Prince William Sound portion of the megathrust with truncated Gutenberg-Richter models for all portions of the megathrust, the parameters for which were estimated from the statistics of instrumentally observed earthquakes. The procedure and the modest changes adopted for 2007 are discussed in more detail herein.

\section{Improvements in Methodology Adopted from the 2002 Revision}

In the process of preparing the 2002 update of the seismic hazard map of the lower 48 States, Frankel and others (2002) made certain improvements in details of the methodology used relative to the 1996 map of the lower 48 States and the 1999 map of Alaska and the Aleutians. These improvements have been adopted in the preparation of the new maps of Alaska and the Aleutians. Principal among these changes were the incorporation of epistemic uncertainty about maximum magnitudes on fault segments and new attenuation relationships. The attenuation relations will be discussed in more detail. For discussion of the treatment of epistemic uncertainty and other minor improvements in the methodology, please see Frankel and others (2002).

The hazard codes of Frankel and others $(1996,2002)$ calculate the frequencies (and probabilities) of exceedance of a predetermined set of ground-motion ordinates. To produce the map it is necessary to interpolate within this relationship to obtain the probabilistic ground-motion values at each point on the map for the desired probability levels. For the 1996 map for the lower 48 States and the 1999 map for Alaska, this interpolation was done in linear space. For the 2002 lower 48 map and the current Alaska map, this interpolation is done in log space. Interpolation in log space is judged to represent the variation in ground motions between the calculated ordinates within the range of the values of interest.

\section{Innovations in Methodology}

We have also modified the hazard programs to allow for position-dependent probabilities owing to variable slip rates along faults. This has allowed us to vary the probability for large earthquakes, for example, along the eastern Denali fault, from a value that reflects $7 \mathrm{~mm} / \mathrm{yr}$ of right-lateral slip where it meets the central Denali fault to one that reflects 2 $\mathrm{mm} / \mathrm{yr}$ at its southern end (Matmon and others, 2006; Plafker and others, 1993). This modification has also allowed us to cascade earthquakes between the central and eastern Denali and the central Denali and Totschunda faults. Another reason for this modification in methodology is to facilitate calculations of earthquake probability involving stress transfer from regional earthquakes, which produce position-dependent stress changes.

\section{Regional Discussion}

\section{Alaska-Aleutian Megathrust}

In the following discussion of the Alaska-Aleutian megathrust, reference is made to subregions that are indicated in figure 7.

\section{Eastern Aleutians to Prince William Sound}

The evidence from geologic studies in the Kodiak area suggests that the underlying portion of the subduction zone ruptures not only in great earthquakes such as the 1964 earthquake (Mw 9.2), but also more frequently in somewhat smaller events (Carver and others, 2003; Sauber and others, in press). Consequently, the 1964 segment used in the 1999 map has been subdivided to allow for the rupture of the Kodiak zone alone about as frequently as it ruptures together with the Prince William Sound portion of the 1964 zone. The maximum magnitude for the Kodiak segment rupturing alone is estimated as $\mathrm{Mw} 8.8$, based on the idea that such an earthquake could have up to one-half the area and one-half the slip of the 1964 earthquake.

Recent detailed studies of earthquakes associated with the megathrust in the Anchorage region (Doser and others, 2004; Ratchkovski and Hansen, 2002b) suggest that the depth of the interface is somewhat less and extends farther north than that assumed in the 1999 maps; thus, we have changed the geometry of the megathrust in the model to reflect better located seismicity. 


\section{Megathrust Sub-zones}

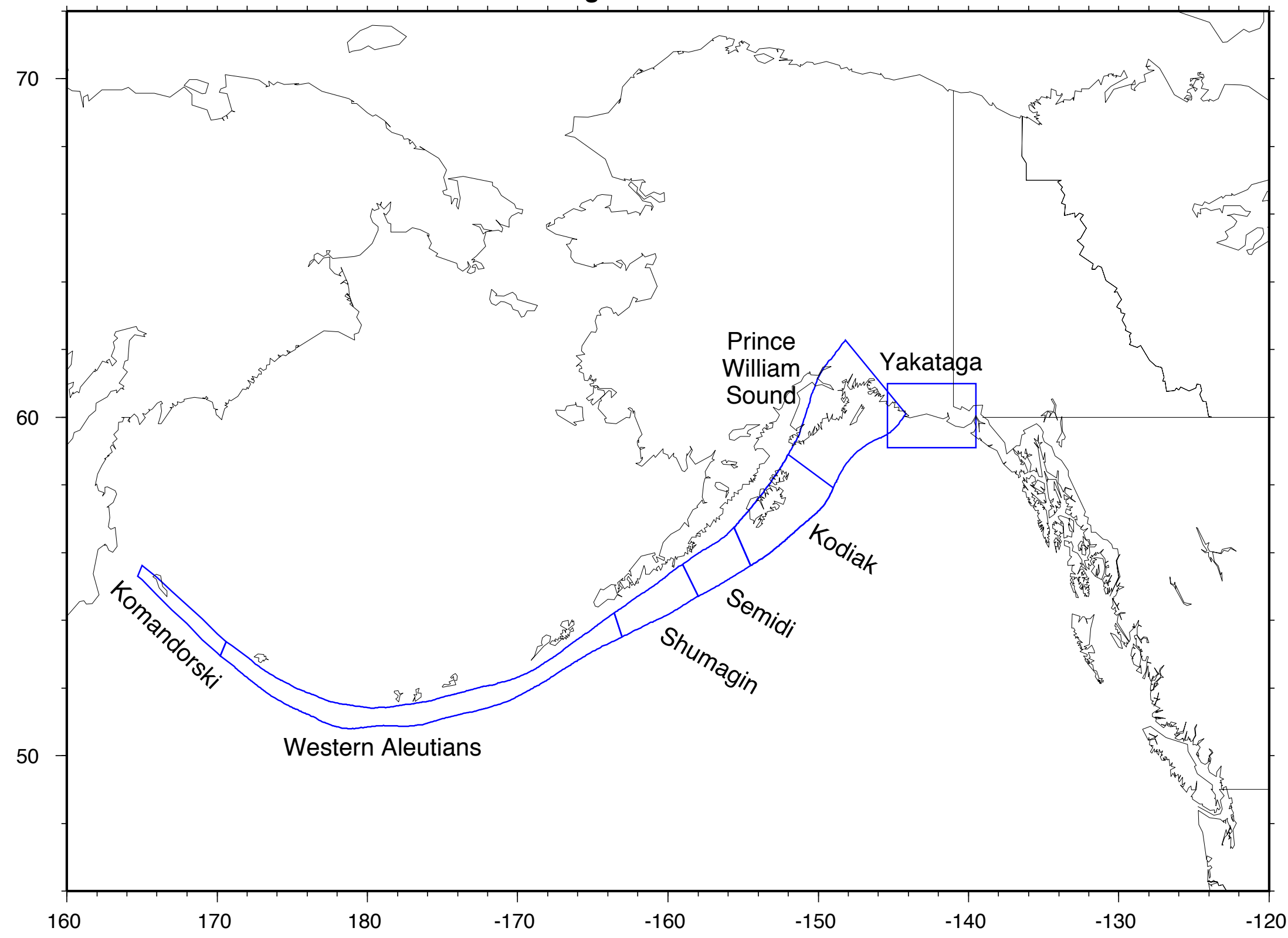

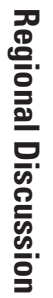

Figure 7. Segmentation of megathrust. 


\section{Semidi Region}

The Semidi region lies between the Kodiak region and the Shumagin gap. It was the location of an Mw 8.2 earthquake in 1938. GPS geodetic observations (Fletcher and others, 2001) indicate the plate interface is fully coupled in this region, in contrast to the largely decoupled region in the Shumagin gap to the west.

\section{Shumagin Gap}

New geodetic evidence that the subduction zone in the region of the Shumagin gap is largely decoupled (Freymueller and Beavan, 1999) tends to support the assumption made in the 1999 maps that great earthquakes are extremely unlikely to rupture through a region near the Shumagin Islands and near the western end of the Alaska Peninsula. Thus, while earthquakes as large as Mw 8 have been observed and are consequently assumed in the map in this region, larger earthquakes are assumed not to rupture through this region.

\section{Western Aleutians}

In the 1999 map the western Aleutians were characterized with a truncated Gutenberg-Richter behavior because it was noted that the $1986 \mathrm{Mw} 8.0$ and $1997 \mathrm{Mw} 7.9$ appeared to rerupture a portion of the rupture area of the 1957 earthquake (Boyd and others, 1995), in apparent violation of classic "characteristic" behavior (as did the $2003 \mathrm{Mw} 7.8$ as well). The work of Johnson and others (1994) supports this assessment. Although Johnson and others revised downward the magnitude of the 1957 earthquake to Mw 8.6 (the value adopted in the catalog for the current map), they specifically concluded that the 1986 earthquake represented a repeated rupture of the main asperity ruptured in 1957.

\section{Komandorski Islands Region}

As discussed previously, in the 1999 map, following the arguments in Cormier (1975), Sykes and others (1981), and Taber and others (1991), the assumption was made that, owing to the highly oblique angle of subduction, the Komandorski Island region was incapable of supporting a great earthquake. This region is, in significant ways, analogous to the tectonic setting along the Andaman trench north of Sumatra. In both cases the current plate motions are highly oblique to the trench with the development of significant strike-slip faulting behind the arc. Despite this highly oblique orientation, rupture in the 2004 Sumatra-Andaman Islands earthquake extended several hundred kilometers into this region of oblique slip, albeit with a considerably lower slip than observed in the regions of more near-trench perpendicular convergence farther to the south (Lay and others, 2005). Thus it seems imprudent to reject the notion that seismic slip along the Komandorski Island section of the arc is possible. Focal mechanisms in the region (fig. 4) show both strike-slip and thrust character with the strike-slip mechanisms occurring particularly to the north of the arc where Geist and Scholl (1994) report geologic evidence of strike-slip faulting.

In the current map, we consider the possibility of thrust earthquakes along the westward extension of the megathrust west of Attu both independent of and in combination with the megathrust farther to the east. Possible strike-slip earthquakes in the region are considered to be modeled by the smoothed seismicity, as discussed in more detail herein.

\section{Yakataga Region}

Although the Yakataga segment is clearly the location of significant north-south convergence and the site of very large earthquakes (for example, 1899, 1979), the details of the faulting are poorly understood. Several east-trending, northdipping thrust faults are inferred to exist beneath the heavily glacier-covered region. Although some studies have been carried out in this region since 1999 (Pavlis and others, 2004), it is not possible at this time to construct a better model of the faulting, and the model assumed is that used in the 1999 map. As a proxy for a more detailed understanding, a flat fault surface (that is, with a $0^{\circ} \mathrm{dip}$ ) at a depth of $15 \mathrm{~km}$ was assumed, extending from $59.1^{\circ}$ to $61.0^{\circ} \mathrm{N}$. and from $139.5^{\circ}$ to $145.4^{\circ}$ $\mathrm{W}$. This is nearly identical to the dislocation model proposed by Sauber and others (1997, 1998; see also Sauber and Molnia, 2004) to explain GPS observations in this region. Sauber and others (1997) estimate that sufficient strain has accumulated in this region since 1899 to generate an earthquake of magnitude Mw 8.1. They also note that there is evidence for about $15 \mathrm{~mm} / \mathrm{yr}$ of right-lateral slip in the regions a few tens of kilometers north of Cape Yakataga.

\section{Detailed Model of Megathrust}

In view of the incremental improvements in understanding of the earthquake-generating characteristics of the megathrust zone, the recurrence model of the zone contains significant modifications from the model used in 1999. Although the results of these modifications to the calculated hazard are relatively subtle, the changes result in a somewhat clearer, more supportable model. As previously discussed, we consider truncated Gutenberg-Richter behavior alone in the western Aleutians, but a combination of Gutenberg-Richter and characteristic behavior in the eastern Aleutians-Kodiak-Prince William Sound region.

Parameters to describe the Gutenberg-Richter behavior for each of the regions along the megathrust are derived from the historical instrumental seismic record. The megathrust was divided into six zones as shown in figure 7. The a- and b-values were calculated for the shallow earthquakes $(0-50 \mathrm{~km})$ in each zone and for the aggregate, excluding the Yakataga zone. The $a-$ and b-values for the individual zones were used to calculate the rates of earthquakes with magnitudes greater than 5 . The 
a- and b-values for the aggregate of the five western zones were used to estimate the rate of earthquakes in the magnitude range 7-8 throughout the western zones. Earthquakes in this magnitude range have been observed throughout the megathrust (with the possible exception of the Komandorski Islands and Prince William Sound regions). The steps taken to characterize the hazard in each of these regions may be summarized as follows:

1. Calculate the $b$-values for

a. earthquakes with depth $50 \mathrm{~km}$ except the megathrust;

b. earthquakes with depth $50 \mathrm{~km}$ for whole megathrust except Yakataga;

c. earthquakes with depth $50 \mathrm{~km}$ for Komandorski, Western Aleutian, Shumagin, Semidi, Kodiak+Kenai/Prince William Sound, and Yakataga subzones individually, all earthquakes with depth $>50$ and $80 \mathrm{~km}$; and

d. all earthquakes with depth $>80$ and $120 \mathrm{~km}$.

2. Calculate and smooth gridded $10^{a}$ values.

a. Smooth $(75 \mathrm{~km})$ for earthquakes with depth 50 $\mathrm{km}$, skip megathrust cells when smoothing cells outside megathrust.

b. Smooth $(50 \mathrm{~km})$ for earthquakes with depth $>50$ and $80 \mathrm{~km}$.

c. Smooth $(50 \mathrm{~km})$ for earthquakes with depth $>80$ and $120 \mathrm{~km}$.

3. Calculate average (rather than gridded) $10^{a}$ value for whole megathrust except Yakataga (depth $50 \mathrm{~km}$ ), then prorate into each cell.

4. Calculate average (rather than gridded) $10^{a}$ value for each megathrust subzone (depth $<50 \mathrm{~km}$ ), then prorate into each cell.

5. Calculate hazard for depth $50 \mathrm{~km}$ and magnitude range 5-7 from Steps 2a and 4 with corresponding $b$-values.

6. Calculate hazard for depth $>50$ and magnitude range 5-7.5 from Steps $2 \mathrm{~b}$ and $2 \mathrm{c}$ with corresponding $b$ values.

7. Calculate hazard for depth $50 \mathrm{~km}$ and magnitude range 7-8 from Step 3 with corresponding $b$-value.

8. Hazard for magnitudes greater than 8:

a. Komandorski subzone: none

b. Western Aleutian subzone: magnitude range 8-9.2 with the $a$-value calculated in Step 4 and the $b$-value calculated in Step 1 c. Shumagin subzone: none

d. Semidi subzone: magnitude range $8-8.5$ with the $a$-value calculated in Step 4 and the $b$-value calculated in Step 1

e. Kodiak subzone alone: characteristic magnitude 8.8 with 650 -year recurrence

f. Kodiak+Kenai/Prince William Sound subzone: characteristic 9.2 (1964-type) with 650-year recurrence

\section{Transition Fault}

The Transition fault is a thrust/oblique slip fault and as such is an important component of the tectonics in the shift from strike-slip displacement along the western margin of the Pacific plate off southeast Alaska to the thrust displacement along the Alaska-Aleutian megathrust to the west. Owing to the fault's location completely beneath the Gulf of Alaska, the fault is insufficiently understood.

In 1999, we treated the Transition fault as an A-type fault, even though its segmentation is unknown. In initial hazard calculations for the 1999 map using a hybrid approach for this fault, we found that the Transition fault produced the highest hazard in the map. The slip rate of the Transition fault is highly uncertain, and we were concerned that one of the more poorly known faults had a higher hazard than the megathrust zone. Thus, we used only the characteristic rupture model for the Transition fault, which produces a lower hazard than the hybrid approach. Also, we used the Youngs and others (1997) subduction zone interface attenuation relation when estimating ground motions for the Transition fault (see "Attenuation Relationships" section). This produces somewhat lower ground motions than do attenuation relations for crustal earthquakes.

In 1999 a slip rate of $10 \mathrm{~mm} / \mathrm{yr}$ was adopted. Review of the plate tectonic and geodetic constraints on the slip rate (DeMets and Dixon, 1999; Fletcher and Freymueller, 2003) suggests that a slip rate of $12 \mathrm{~mm} / \mathrm{yr}$ is more appropriate. The low number of large earthquakes on the fault, however, seem to be at odds with this slip rate, although it is possible that some the large earthquakes in 1899 could be associated with this fault (Doser, 2006). On the subduction zone to the west it is clear that a variable, but perhaps substantial, fraction of the slip is accommodated as aseismic slip (Pacheco and others, 1993). By analogy, but somewhat arbitrarily, we have therefore allowed 50 percent of the slip across the transition fault to be accommodated aseismically and assume that 6 $\mathrm{mm} / \mathrm{yr}$ is released in characteristic events of magnitude 8.2 every 325 years.

\section{Fairweather and Queen Charlotte Faults}

Improved understanding of the segmentation along the Fairweather-Queen Charlotte fault system (fig. 8), plate 
motion studies specific to the North American and Pacific plates (DeMets and Dixon, 1999), and GPS studies (Freymueller and Fletcher and 1999; Fletcher and Freymueller, 2003; Mazzotti and others, 2003; Smith and others, 2003), have led to several modifications of the seismic hazard attributable to the Fairweather and Queen Charlotte faults.

In 1999, the boundary between the onshore and offshore Fairweather fault segments were drawn on the basis of the notations shown on the map of Plafker and others (1993). These extents did not coincide with the extent of aftershocks for these earthquakes drawn on the same map. Following the arguments of Bufe (2005) our segment boundaries have changed to reflect the aftershock distributions, moving the segment boundary about $100 \mathrm{~km}$ to the southwest. This leads to longer onshore and shorter offshore Fairweather fault segments.

Plate-motion studies using geologic and GPS constraints (DeMets and Dixon, 1999) clearly show a reduction in relative plate velocity between the North American and Pacific plates along the Queen Charlotte fault relative to velocities used in the 1999 hazard maps. In 1999 we adopted a value of 58 mm/ yr. According to the aforementioned studies, this value has been reduced to $49 \mathrm{~mm} / \mathrm{yr}$ and increases by $1 \mathrm{~mm} / \mathrm{yr}$ toward the northwestern end of the Fairweather fault. Because of the partitioning of strain between the eastern Denali ( $2 \mathrm{~mm} / \mathrm{yr})$ and Fairweather faults (Fletcher and Freymueller, 2003), we have adopted a value of $48 \mathrm{~mm} / \mathrm{yr}$ for the onshore portion of the Fairweather fault.

Mazzotti and others (2003) suggested that a significant component of convergence perpendicular to the fault exists at the southern end of the Queen Charlotte system. This convergence is not explicitly modeled in the preparation of the map, although to some degree the hazard can be taken as modeled by the smoothed seismicity.

\section{Central Denali, Totschunda, and Eastern Denali Faults}

Results of geologic studies carried out since the 2002 Denali earthquake have required changes to the models of the central and eastern Denali and Totschunda faults (fig. 9) relative to what was used in 1999 (Schwartz and others, 2005a and b; Matmon and others, 2006). The best current information suggests that the slip rate on the central Denali increases in an eastern direction along the fault from about $9 \mathrm{~mm} / \mathrm{yr}$ near

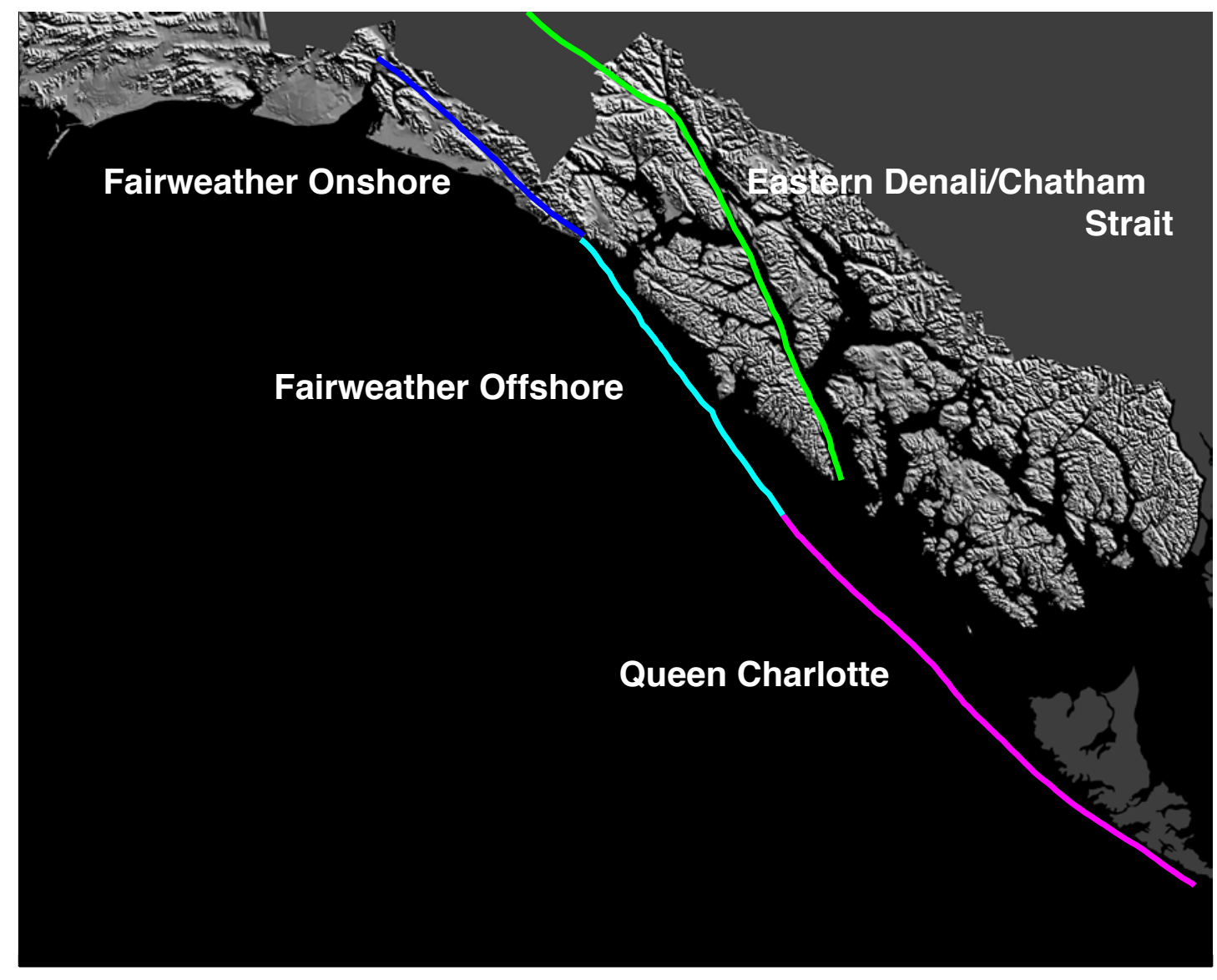

Figure 8. Active crustal faults in south-east Alaska. 
the Parks Highway to about $14 \mathrm{~mm} / \mathrm{yr}$ at the junction with the Totschunda fault. Current understanding suggests that this slip rate is portioned into about $8 \mathrm{~mm} / \mathrm{yr}$ on the eastern Denali fault and about $6 \mathrm{~mm} / \mathrm{yr}$ on the Totschunda fault. The slip rate on the eastern Denali fault continues to decrease with distance to the east to values of $2 \mathrm{~mm} / \mathrm{yr}$ or less in Canada near Kluane Lake, although Fletcher and Freymueller (2003) suggest that it may be higher. In the 1999 map, constant slip rates of 10 $\mathrm{mm} / \mathrm{yr}$ were assumed for the central Denali fault, $2 \mathrm{~mm} / \mathrm{yr}$ for the eastern Denali, and $11.5 \mathrm{~mm} / \mathrm{yr}$ for the Totschunda. One further implication of the new information is that ruptures extending eastward from the central Denali fault are about equally likely to continue onto the eastern Denali and Totschunda faults.

Two observations from the 2002 Denali earthquake and the resulting studies motivated modifications to the standard approach to calculation for the National Seismic Hazard Map. First, as previously noted, the 2002 earthquake branched from the central Denali fault to the Totschunda fault, but new geologic evidence implies that the continuation of rupture onto the eastern Denali fault is about equally likely. Second, the slip rate on the eastern Denali fault, and to a lesser extent, on the central Denali fault, clearly varies with position along the fault. The first of these issues was addressed by considering two fault models, one including the eastern Denali fault at its full slip rate plus the central Denali fault with 8/14 of its slip rate, and another model with the Totschunda fault together with the central Denali fault with $6 / 14$ of its slip rate. The proportions for the central Denali were derived from the relative partitioning of slip onto the eastern Denali and Totschunda faults. Then, in the hazard codes, earthquakes are allowed to float the full length of the combined faults in each model.

The second modification incorporated into these calculations was the ability to change the frequency of earthquakes of any particular magnitude in proportion to the observed slip rate. For example, the characteristic magnitude assumed for the central and eastern Denali fault model was Mw 7.9. In the hazard calculations, the frequency of such earthquakes is assumed to be five times greater along the reach of the fault characterized by a slip rate of $10 \mathrm{~mm} / \mathrm{yr}$ as contrasted with the reach of the fault characterized by a slip rate of $2 \mathrm{~mm} / \mathrm{yr}$. Similarly, when considering earthquakes of lower magnitudes, the same ratio is applied. Although some might argue that portions of the faults characterized by higher slip rates might also have a different magnitude distribution (likely with higher magnitudes), we judge the current modification to be a significant improvement over the existing methodology and leave further improvements for subsequent revisions of the hazard maps.

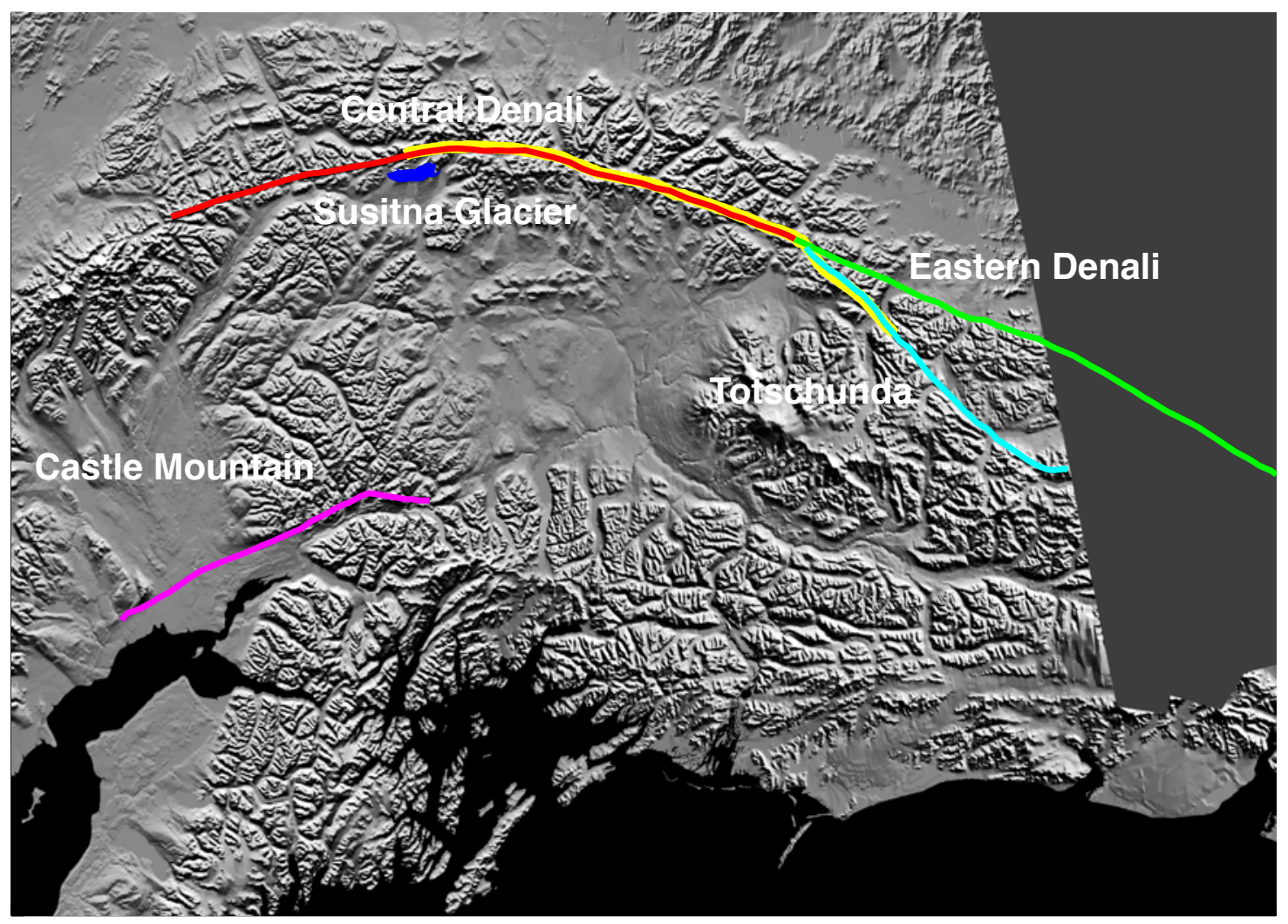

Figure 9. Active crustal faults in south-central Alaska. The yellow line shows the surface ruptures associated with the 2002 Denali fault earthquake. 
We also take advantage of these modifications to address the hazard at the western end of the active Denali fault. In the 1999 map, the end of the active fault was taken to be at about longitude $150.2^{\circ} \mathrm{W}$. Published sources reviewed in the new Quaternary Fault and Fold Database of the United States. (http://earthquake.usgs.gov/regional/qfaults/) provide evidence for extending the active fault to the west with a slip rate gradually tapering to zero. Thus we have tapered the slip rate on the Denali fault linearly from $9.4 \mathrm{~mm} / \mathrm{year}$ at about $150.2^{\circ} \mathrm{W}$. to $0 \mathrm{~mm} /$ year at about $154.7^{\circ} \mathrm{W}$.

These modifications allowing the use of positiondependent probabilities along faults also permit application of time-dependent hypotheses such as the variation of slip-deficit and Coulomb stress changes along faults. We are currently working on experimental time-dependent hazard maps exploiting these capabilities.

\section{Castle Mountain Fault}

The Castle Mountain fault (fig. 9) is particularly important to estimation of the seismic hazard in the vicinity of Anchorage because it is located at a distance of only about 40 $\mathrm{km}$ from the city and even closer to the developing areas to the north of the city. In the 1999 map, the fault was considered as two segments, the western or Susitna segment and the eastern or Talkeetna segment (Detterman and others, 1974). Along the Talkeetna segment there is no evidence for surficial displacement younger than Pleistocene (Detterman and others, 1976), but Lahr and others (1986) describe an earthquake of Ms 5.2, which indicated slip at a depth of 13 to $20 \mathrm{~km}$ along the segment. In contrast, along the Susitna segment, no significant earthquakes have been instrumentally located, but geologic studies indicate Holocene surface displacement (Detterman and others, 1974, 1976; Bruhn, 1979). At the time of preparation of the 1999 maps, these studies, however, had served only to put wide limits on the slip rate. At the time, we chose a value of $0.5 \mathrm{~mm} / \mathrm{yr}$ and a maximum magnitude of 7.5 , leading to a recurrence time of 1,300 years.

The new geologic data for the Castle Mountain fault near Houston, Alaska, on the Susitna segment (Haeussler and others, 2002; Willis and others, in press) suggest slip rates as high as $3.2 \mathrm{~mm} / \mathrm{yr}$, compared to the value of $0.5 \mathrm{~mm} / \mathrm{yr}$ assumed in 1999, and an average recurrence time of about 700 years based on the interpretation of four paleoearthquakes. We have assumed a rate of $2.9 \mathrm{~mm} / \mathrm{yr}$, and the estimate of characteristic or maximum magnitude has been reduced from 7.5 to 7.1. These changes led to a faster slip rate and somewhat smaller, but more frequent events, and significantly increased the seismic hazard from this fault.

\section{Kodiak Crustal Faults}

Work by Carver and others (2003) on the southeastern edge of Kodiak Island indicates a series of left-lateral strike-slip faults trending northeast, subparallel to the subduction-zone trench. Enough information has been compiled on these faults to warrant their inclusion into the current set of maps. We have assigned a slip rate of $1 \mathrm{~mm} / \mathrm{yr}$ to the Narrow Cape fault and $2 \mathrm{~mm} / \mathrm{yr}$ to the Kodiak fault and allowed both characteristic and Gutenberg-Richter behavior with magnitudes of 7.5 and $6.5-7.5$, respectively. It is possible that some of this observed movement could be coincident with large subduction-zone events.

\section{Other Sources Modeled with Smoothed Seismicity}

\section{Strike-Slip Faults Subparallel to Arc}

At the western end of the Aleutian arc in the vicinity of Bering Island, where the relative direction of plate movement between the Pacific and North American plates is nearly parallel to the arc, it is clear that a very significant portion of this slip is partitioned along right-lateral strike-slip faults both to the north and south of the Aleutian arc (c.f. Geist and Scholl, 1994). Near Bering Island (166.5 ${ }^{\circ}$ E.) recent GPS studies suggest that as much as $50 \mathrm{~mm} / \mathrm{yr}$ is accommodated on strikeslip zones to the north of the island (Buergmann and others, 2005). Earthquake focal mechanisms and geologic studies, especially from bottom and sub-bottom profiling, suggest that these faults extend eastward along the arc at least as far as $160^{\circ} \mathrm{W}$. From geometric considerations it seems likely that the amount of slip that is partitioned into the strike-slip faults decreases eastward as the portion of the slip tangential to arc decreases; that is, as the angle between the plate motion and the arc increases from nearly zero at the western end of the arc to nearly perpendicular at the eastern end.

Slip rates are unknown for individual faults within this group, and thus, hazard must be captured in the smoothed seismicity.

\section{Cook Inlet}

Recent studies by Doser and others (2004) and Haeussler and others (2000) have investigated earthquakes that are associated with crustal faults and folds in the Cook Inlet region. Other than for the Castle Mountain fault, insufficient information exists to explicitly characterize the seismic hazard from individual faults in this region. Significant hazard is captured in the maps, however, through the smoothed seismicity.

\section{Tintina/Kaltag Fault}

The Tintina fault (fig. 1) is a major right-lateral fault about 1,500 km long, extending from north-central Alaska southeastward to British Columbia. The fault displaces midCretaceous rocks and lower Paleozoic facies boundaries by 450 km (Roddick, 1967; Gabrielse, 1985). To the southeast 
the fault is associated with the Rocky Mountain Trench. Little earthquake activity is associated with this fault in the Yukon (Hyndman and others, 2005). Although there is evidence for late Pleistocene movement along the Kaltag fault (the westward extension of the Tintina) and possibly Holocene activity along the Medicine Lake lineament (Plafker and others, 1993), there is insufficient information to include the fault explicitly as a source. Some earthquake potential from this fault is captured in the smoothed seismicity.

\section{Region Between the Denali and Tintina/Kaltag Faults}

The region of interior Alaska between the Denali and Tintina/Kaltag faults experienced several earthquakes in the magnitude 7 range during the 20th century and, in addition, has a number of young faults. The earthquakes include the events of July 22, 1937, October 16, 1947, and April 7, 1958 (Fletcher and Christensen, 1996). Many of the smaller earthquakes in the region are concentrated in three diffuse bands striking north-northeast. These bands have been termed the Minto Flats, Fairbanks, and Salcha seismic zones (Page and others, 1995; Ratchkovski and Hansen, 2002a). To date, none of these bands have been clearly associated with a geologic fault. There are, however, a number of northeast- to northnortheast-striking faults along the north side of the Denali fault with evidence of youthful activity. Primary examples of these include the Donnelly Dome and Canteen faults. Several of these faults have received recent attention (for example Bemis, 2004; L.S. Cluff, G. Plafker, G. Carver, oral commun., 2005), but as of this writing, insufficient information is available to include any individual fault explicitly; thus, the hazard they present is captured in the smoothed seismicity.

\section{Attenuation Relationships}

The set of attenuation relations used in this revision of the map is shown in table 2 .

Relative to 1999, the set of attenuation relationships used for the 2002 National Seismic Hazard Map for the lower 48 States and also used here on average tend to give slightly lower ground motions than the set used in 1999 (Frankel and others, 2002). One important exception to this is that the addition of the Sadigh relation for the shallow subduction earthquakes tends to increase ground motions.

As in the 1999 map, the reference site condition is the NEHRP B/C boundary, which corresponds to an average shear-wave velocity of $760 \mathrm{~m} / \mathrm{sec}$ in the top $30 \mathrm{~m}$. This is the same site condition used in the 1996 national maps. This site condition represents a typical Western United States "firmrock" site. Table 2 shows the ground-motion relationships used in the calculations. These are the same relations used in producing the 1996 hazard maps for the Western United States. For crustal faults we used different ground-motion values for thrust faults and for strike-slip faults, using the values specified in each attenuation study. For the deep earthquakes, we assumed a focal depth of $60 \mathrm{~km}$ for earthquakes in the depth interval 50 to $80 \mathrm{~km}$ and a focal depth of $90 \mathrm{~km}$ for earthquakes in the depth interval 80 to $120 \mathrm{~km}$. In the 50 to $80-\mathrm{km}$ range, the distribution of earthquakes is strongly biased toward the shallower depths, justifying the choice of an assumed depth less than the midpoint of the interval. In the 80 - to $120-\mathrm{km}$ range, the distribution of earthquakes in the Kodiak and Prince William Sound regions is also biased toward shallower depths, and a similar argument can be made. Further to the west along the arc, the distribution is more uniform with depth in this interval, although the number of events is fewer than in the Kodiak and Prince William Sound regions. For shallow earthquakes, focal depths of 5 $\mathrm{km}$ were assumed.

\section{Calculation Procedure}

The overall calculation procedure is summarized in table 3, which describes the input files, key input parameters, and the hazard codes used. In general, hazard curves relating ground motions to frequencies of exceedance are generated for the series of sources previously outlined. The hazard curves at each latitude and longitude are combined, and a groundmotion value for a desired frequency of exceedance corresponding to a particular probability level is interpolated from the curves. The resulting ground-motion values constitute the probabilistic seismic hazard maps.

\section{Resulting Maps}

Figures 10-13 show the resulting maps for the entire region of Alaska and the Aleutians. Figure 10 shows the maps for the probability level of 2 percent in 50 years for peak ground acceleration (PGA) (fig. 10A), $0.2 \mathrm{sec}$ spectral amplitude (SA) (fig. 10B), and $1.0 \mathrm{sec} \mathrm{SA}$ (fig. 10C). Figure 11 shows the same PGA and SA for the probability levels of 10 percent in 50 years. Figure 12 shows PGA at 2 percent in 50 years at an expanded scale for the Aleutians, south-central Alaska and the 1964 earthquake zone, and southeast Alaska. 
Table 2. Attenuation relationships assumed for various seismic sources. $[\%$, percent $]$

\begin{tabular}{|c|c|c|}
\hline Source & Attenuation Relationship & Weight \\
\hline $\begin{array}{l}\text { Megathrust and } \\
\text { Transition fault }\end{array}$ & $\begin{array}{l}\text { Youngs et al. (1997) (interface) } \\
\text { Sadigh et al (1997) }\end{array}$ & $50 \%$ each $^{1}$ \\
\hline Crustal faults & $\begin{array}{l}\begin{array}{l}\text { Abrahamson and Silva (1997) } \\
\text { (rock) }\end{array} \\
\text { Boore et al (1997) (NEHRP B/C) } \\
\text { Sadigh et al. (1997) (rock) } \\
\text { Campbell and Bozorgnia (2003) } \\
\text { Site conditions as in Frankel and } \\
\text { others (2003) }\end{array}$ & $25 \%$ each \\
\hline $\begin{array}{l}\text { Shallow smoothed } \\
\text { seismicity } \\
\text { (including in zone } \\
\text { of megathrust) } \\
(\text { depth }=0-50 \mathrm{~km})\end{array}$ & $\begin{array}{l}\text { Same as for crustal faults, but } \\
\text { with corrections for random } \\
\text { mechanisms } \\
\text { (see Frankel and others, 2003) }\end{array}$ & $25 \%$ each \\
\hline $\begin{array}{l}\text { Deep earthquakes } \\
(\text { depth }=50-80 \mathrm{~km})\end{array}$ & $\begin{array}{l}\text { Youngs et al. (1997) (intraslab; } \\
\text { depth fixed at } 60 \mathrm{~km} \text { ) } \\
\text { Atkinson and Boore (2003) } \\
\text { (global) }\end{array}$ & $50 \%$ each \\
\hline $\begin{array}{l}\text { Deeper earthquakes } \\
\text { (depth }=80-120 \mathrm{~km})\end{array}$ & $\begin{array}{l}\text { Youngs et al. (1997) (intraslab; } \\
\text { depth fixed at } 90 \mathrm{~km} \text { ) } \\
\text { Atkinson and Boore (2003) } \\
\text { (global) }\end{array}$ & $50 \%$ each \\
\hline
\end{tabular}

${ }^{1}$ At distances greater than $70 \mathrm{~km}$, full weight is given to Youngs et al. (1997) 
Table 3. Input files, key parameters, and hazard codes used in preparing the maps.

[km, kilometer; ${ }^{\circ}$, degrees; $\mathrm{mm} / \mathrm{yr}$, millimeters per year]

\begin{tabular}{|c|c|c|c|c|c|c|c|c|c|c|c|c|}
\hline 'Input file & Source & $\begin{array}{l}\text { Magnitude } \\
\text { range }\end{array}$ & a & b & Length $(\mathrm{km})$ & $\begin{array}{l}\text { Depth } \\
(\mathrm{km})\end{array}$ & $\begin{array}{l}\text { Dip } \\
\left(^{\circ}\right)\end{array}$ & dmag & $\begin{array}{l}\text { Hazard } \\
\text { program }\end{array}$ & $\begin{array}{l}\text { Assumed } \\
\text { depth }\end{array}$ & Attenuation relationships & Weight \\
\hline megaAll.out_revF.in & Entire Aleutian arc & $\begin{array}{l}\text { G-R } \\
7 \text { to } 8\end{array}$ & 3.540 & 0.689 & & $20-50$ & & 0.1 & hazSUBXv3 & Calculated & $\begin{array}{l}{ }^{2} \text { Youngs and others (1997) (interface) } \\
\text { Sadigh and others (1997) }\end{array}$ & 1.0 \\
\hline megaeast.out_revF.in & $\begin{array}{l}\text { Eastern Aleutians } \\
\text { and } 1964 \text { zone }\end{array}$ & $\begin{array}{l}\text { Characteristic } \\
9.2\end{array}$ & 6.387 & 1.000 & & $20-42$ & & 0.0 & hazSUBXv3 & Calculated & $\begin{array}{l}{ }^{2} \text { Youngs and others (1997) (interface) } \\
\text { Sadigh and others (1997) }\end{array}$ & 1.0 \\
\hline megaA.out_revF.in & Western Aleutians & $\begin{array}{l}\text { G-R } \\
8 \text { to } 9.2\end{array}$ & 3.160 & 0.660 & & $20-50$ & & 0.1 & hazSUBXv3 & Calculated & $\begin{array}{l}{ }^{2} \text { Youngs and others (1997) (interface) } \\
\text { Sadigh and others (1997) }\end{array}$ & 1.0 \\
\hline megaF.out_revF.in & Far Western Aleutians & $\begin{array}{l}G-R \\
8 \text { to } 9.2\end{array}$ & 2.690 & 0.773 & & $20-50$ & & 0.1 & hazSUBXv3 & Calculated & $\begin{array}{l}{ }^{2} \text { Youngs and others (1997) (interface) } \\
\text { Sadigh and others (1997) }\end{array}$ & 1.0 \\
\hline megaB.out_revF.in & Semidi region & $\begin{array}{l}\text { G-R } \\
8 \text { to } 8.5\end{array}$ & 2.400 & 0.710 & & $20-50$ & & 0.1 & hazSUBXv3 & Calculated & $\begin{array}{l}{ }^{2} \text { Youngs and others (1997) (interface) } \\
\text { Sadigh and others (1997) }\end{array}$ & 1.0 \\
\hline megaD.out_revF.in & Kodiak segment & $\begin{array}{l}\text { Characteristic } \\
8.8\end{array}$ & 5.987 & 1.000 & & $20-42$ & & 0.0 & hazSUBXv3 & Calculated & $\begin{array}{l}{ }^{2} \text { Youngs and others (1997) (interface) } \\
\text { Sadigh and others (1997) }\end{array}$ & 1.0 \\
\hline yak.out_revF.in & Yakataga & $\begin{array}{l}\text { G-R } \\
7 \text { to } 8.1\end{array}$ & 2.180 & 0.666 & & 15 & & 0.1 & hazSUBXv3 & Calculated & $\begin{array}{l}\text { 2Youngs and others (1997) (interface) } \\
\text { Sadigh and others (1997) }\end{array}$ & 1.0 \\
\hline trans.out_revF.in & Transition zone & $\begin{array}{l}\text { Characteristic } \\
8.2\end{array}$ & 5.687 & 1.000 & & $0-15$ & & 0.0 & hazSUBXv3 & Calculated & $\begin{array}{l}{ }^{2} \text { Youngs and others (1997) (interface) } \\
\text { Sadigh and others (1997) }\end{array}$ & 1.0 \\
\hline AKML75.out_revF.in & $\begin{array}{l}\text { Shallow earthquakes } \\
\text { Depth } 0 \text { to } 50 \mathrm{~km} \\
\text { Smoothed at } 75 \mathrm{~km}\end{array}$ & $\begin{array}{l}\text { G-R } \\
5 \text { to } 7.3\end{array}$ & \begin{tabular}{|l} 
GridsR4/ \\
a_000d050_xmt.out
\end{tabular} & 0.816 & & $0-50$ & & 0.1 & hazgridXv3 & $5 \mathrm{~km}$ & $\begin{array}{l}\text { Same as crustal faults but with } \\
\text { corrections for random mechanisms }\end{array}$ & 1.0 \\
\hline AKMT.out_revF.in & $\begin{array}{l}\text { Source zones corresponding } \\
\text { to the megathrust }\end{array}$ & $\begin{array}{l}\text { G-R } \\
5 \text { to } 7\end{array}$ & \begin{tabular}{|l|} 
GridsR3/ \\
a_000d050_mt.out_sw
\end{tabular} & \multicolumn{2}{|c|}{$\begin{array}{l}\text { GridsR3/ } \\
\text { b_000d050_mt.out_sw }\end{array}$} & $0-50$ & & 0.1 & hazgridXv3 & $5 \mathrm{~km}$ & $\begin{array}{l}\text { Same as crustal faults but with } \\
\text { corrections for random mechanisms and } \\
\text { half thrust for Boore and Sadigh }\end{array}$ & 1.0 \\
\hline AKDEEP.out_revF.in & \begin{tabular}{|l|} 
Deep earthquakes \\
Depth 50 to $80 \mathrm{~km}$
\end{tabular} & $\begin{array}{l}\text { G-R } \\
5 \text { to } 7.5\end{array}$ & $\begin{array}{l}\text { GridsR3/ } \\
\text { a_051d080.out_sw }\end{array}$ & 0.858 & & $50-80$ & & 0.1 & hazgridXv3 & $60 \mathrm{~km}$ & $\begin{array}{l}\text { Youngs and others (1997) (intraslab) } \\
\text { Atkinson and Boore (2002) (global) }\end{array}$ & 1.0 \\
\hline AKDEEPER.out_revF.in & \begin{tabular}{|l|} 
Deeper earthquakes \\
Depth 80 to $120 \mathrm{~km}$
\end{tabular} & $\begin{array}{l}\text { G-R } \\
5 \text { to } 7.5\end{array}$ & \begin{tabular}{|l} 
GridsR3/ \\
a_081d120.out_sw
\end{tabular} & 1.007 & & $80-120$ & & 0.1 & hazgridXv3 & $90 \mathrm{~km}$ & $\begin{array}{l}\text { Youngs and others (1997) (intraslab) } \\
\text { Atkinson and Boore (2003) (global) }\end{array}$ & 1.0 \\
\hline AKF5.out_revF.in & $\begin{array}{l}\text { Kodiak Island fault, } 1 \mathrm{~mm} / \mathrm{yr} \\
\text { Narrow Cape faults, } 2 \mathrm{~mm} / \mathrm{yr}\end{array}$ & $\begin{array}{l}\text { Characteristic } \\
7.5 \\
7.5\end{array}$ & $\begin{array}{l}3.198 \\
3.465\end{array}$ & $\begin{array}{l}0.870 \\
0.870\end{array}$ & $\begin{array}{l}208.82 \\
193.20\end{array}$ & $\begin{array}{l}15 \\
15\end{array}$ & $\begin{array}{l}90 \\
90\end{array}$ & $\begin{array}{l}0.0 \\
0.0\end{array}$ & hazFXv6 & Calculated & $\begin{array}{l}\text { Abrahamson and Silva (1997) rock } \\
\text { Boore and others (1997) NEHRP B/C } \\
\text { Sadigh and others (1997) rock } \\
\text { Campbell and Bozorgnia (2003) }\end{array}$ & 0.5 \\
\hline AKF4.out_revF.in & $\begin{array}{l}\text { Kodiak Island fault, } 1 \mathrm{~mm} / \mathrm{yr} \\
\text { Narrow Cape faults, } 2 \mathrm{~mm} / \mathrm{yr}\end{array}$ & \begin{tabular}{|l|} 
G-R \\
6.5 to 7.5 \\
6.5 to 7.5
\end{tabular} & $\begin{array}{l}2.476 \\
2.743\end{array}$ & 0.870 & $\begin{array}{l}208.82 \\
193.20\end{array}$ & $\begin{array}{l}15 \\
15\end{array}$ & $\begin{array}{l}90 \\
90\end{array}$ & $\begin{array}{l}0.1 \\
0.1\end{array}$ & hazFXv6 & Calculated & $\begin{array}{l}\text { Abrahamson and Silva (1997) rock } \\
\text { Boore and others (1997) NEHRP B/C } \\
\text { Sadigh and others (1997) rock } \\
\text { Campbell and Bozorgnia (2003) }\end{array}$ & 0.5 \\
\hline AKF1.out_revF.in & $\begin{array}{l}\text { Queen Charlotte, } 49.0 \mathrm{~mm} / \mathrm{yr} \\
\text { Fairweather offshore, } 49.5 \mathrm{~mm} / \mathrm{yr} \\
\text { Fairweather onshore, } 48.0 \mathrm{~mm} / \mathrm{yr}\end{array}$ & $\begin{array}{l}\text { Characteristic } \\
8.1 \\
7.7 \\
8.0\end{array}$ & $\begin{array}{l}6.4923 \mathrm{e}-3 \\
9.8952 \mathrm{e}-3 \\
6.5652 \mathrm{e}-3\end{array}$ & & $\begin{array}{l}466.65 \\
176.85 \\
341.03\end{array}$ & $\begin{array}{l}15 \\
15 \\
15\end{array}$ & $\begin{array}{l}90 \\
90 \\
90\end{array}$ & $\mid \begin{array}{l}0.0 \\
0.0 \\
0.0\end{array}$ & hazFXv6 & Calculated & $\begin{array}{l}\text { Abrahamson and Silva (1997) rock } \\
\text { Boore and others (1997) NEHRP B/C } \\
\text { Sadigh and others (1997) rock } \\
\text { Campbell and Bozorgnia (2003) }\end{array}$ & 0.5 \\
\hline AKF0.out_revF.in & $\begin{array}{l}\text { Queen Charlotte and } \\
\text { Fairweather at } 49 \mathrm{~mm} / \mathrm{yr}\end{array}$ & \begin{tabular}{|l|}
$G-R$ \\
$7.6-8.1$
\end{tabular} & 4.635 & 0.870 & 987.81 & 15 & 90 & 0.1 & hazFXv6 & Calculated & $\begin{array}{l}\text { Abrahamson and Silva (1997) rock } \\
\text { Boore and others (1997) NEHRP B/C } \\
\text { Sadigh and others (1997) rock } \\
\text { Campbell and Bozorgnia (2003) }\end{array}$ & 0.5 \\
\hline AKF2.out_revF.in & $\begin{array}{l}\text { Western + Eastern Denali } \\
\text { 1-9.4-14.4,8.4-2 mm/yr } \\
\text { Western Denali + Totschunda } \\
\text { 1-9.4-14.4 mm/yr, } 6 \mathrm{~mm} / \mathrm{yr} \\
\text { Castle Mtn, 0.5-2.9-0.5 mm/yr }\end{array}$ & $\begin{array}{l}\text { Characteristic } \\
7.9 \\
7.9 \\
7.1\end{array}$ & $\begin{array}{l}4.53 .82225(3.58817)-4.79538(4.56130)- \\
4.98061(4.74653), 4.74653-4.12328 \\
3.54382(3.16361)-4.51695(4.13674)- \\
4.70219(4.32197), 4.32197 \\
3.12184-3.88527-3.12184\end{array}$ & $\begin{array}{l}0.870 \\
0.870 \\
0.870\end{array}$ & $\begin{array}{l}1570.5 \\
827.2 \\
189.5\end{array}$ & $\begin{array}{l}15 \\
15 \\
15.529\end{array}$ & $\begin{array}{l}90 \\
90 \\
-75\end{array}$ & $\begin{array}{l}0.0 \\
0.0 \\
0.0\end{array}$ & hazFXv7 & Calculated & $\begin{array}{l}\text { Abrahamson and Silva (1997) rock } \\
\text { Boore and others (1997) NEHRP B/C } \\
\text { Sadigh and others (1997) rock } \\
\text { Campbell and Bozorgnia (2003) }\end{array}$ & 0.5 \\
\hline AKF3.out_revF.in & $\begin{array}{l}\text { Western + Eastern Denali } \\
\text { 1-9.4-14.4,8.4-2 mm/yr } \\
\text { Western Denali + Totschunda } \\
\text { 1-9.4-14.4 mm/yr, } 6 \mathrm{~mm} / \mathrm{yr} \\
\text { Castle Mtn, 0.5-2.9-0.5 mm/yr }\end{array}$ & $\begin{array}{l}\text { G-R } \\
6.5 \text { to } 7.9 \\
6.5 \text { to } 7.9 \\
6.5 \text { to } 7.1\end{array}$ & $\begin{array}{l}4.53 .04528(2.81119)-4.01841(3.78432)- \\
4.20364(3.96956), 3.96956-3.34631 \\
2.76685(2.38664)-3.73998(3.35977)- \\
3.92521(3.54500), 3.54500 \\
2.51945-3.28288-2.51945\end{array}$ & $\begin{array}{l}0.870 \\
0.870 \\
0.870\end{array}$ & $\begin{array}{l}1570.5 \\
827.2 \\
189.5\end{array}$ & $\begin{array}{l}15 \\
15 \\
15.529\end{array}$ & $\begin{array}{l}90 \\
90 \\
-75\end{array}$ & $\begin{array}{l}0.1 \\
0.1 \\
0.1\end{array}$ & hazFXv7 & Calculated & $\begin{array}{l}\text { Abrahamson and Silva (1997) rock } \\
\text { Boore and others (1997) NEHRP B/C } \\
\text { Sadigh and others (1997) rock } \\
\text { Campbell and Bozorgnia (2003) }\end{array}$ & 0.5 \\
\hline
\end{tabular}


A.

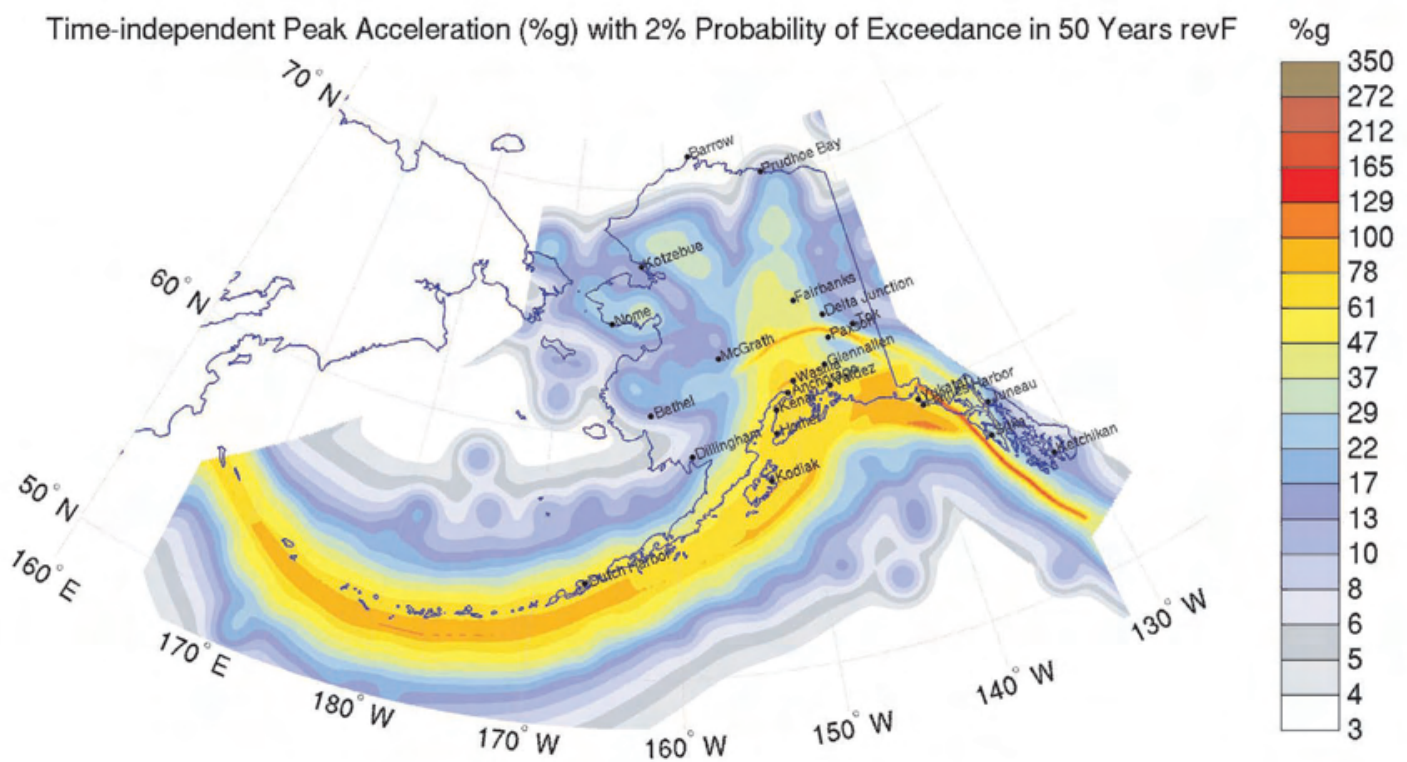

B. Time-independent $0.2 \mathrm{sec}$ Spectral Accel. (\%g) with $2 \%$ Probability of Exceedance in 50 Years revF \%g

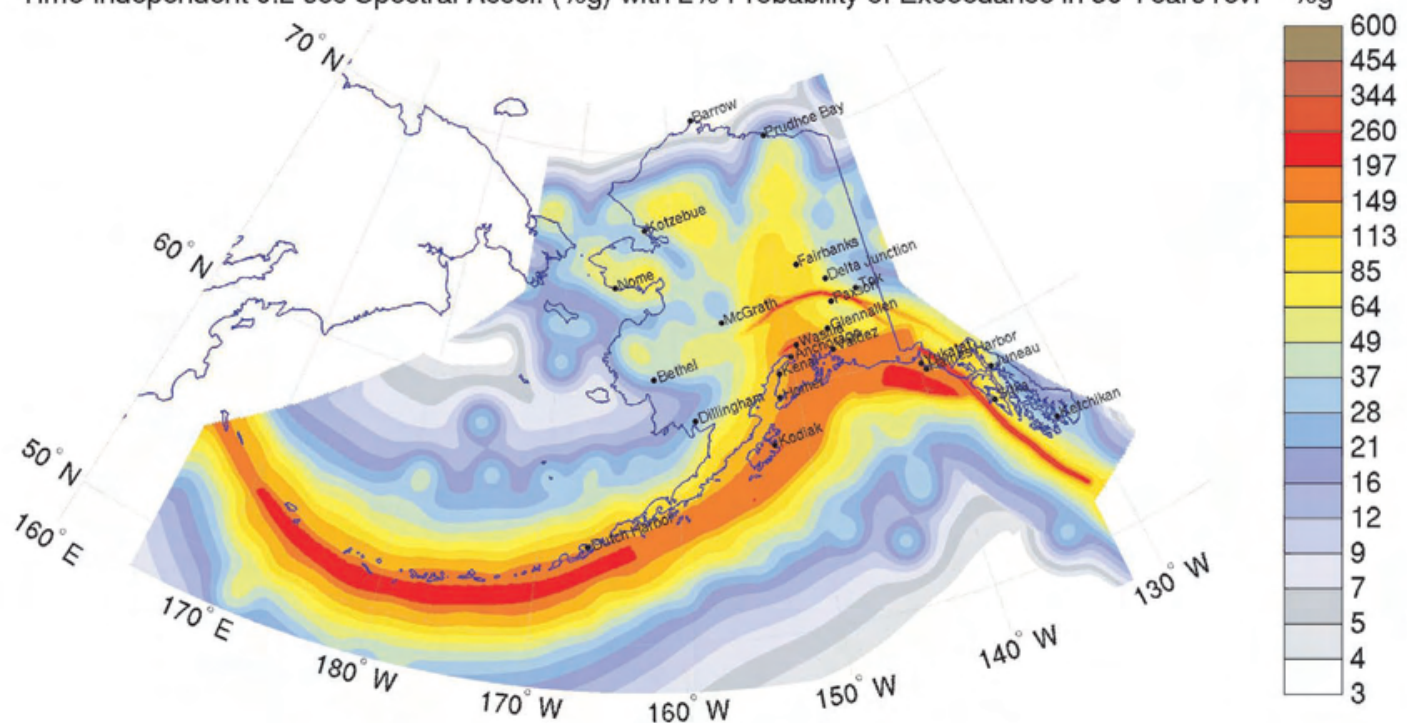

C. Time-independent $1.0 \mathrm{sec}$ Spectral Accel. (\%g) with $2 \%$ Probability of Exceedance in 50 Years revF \%g

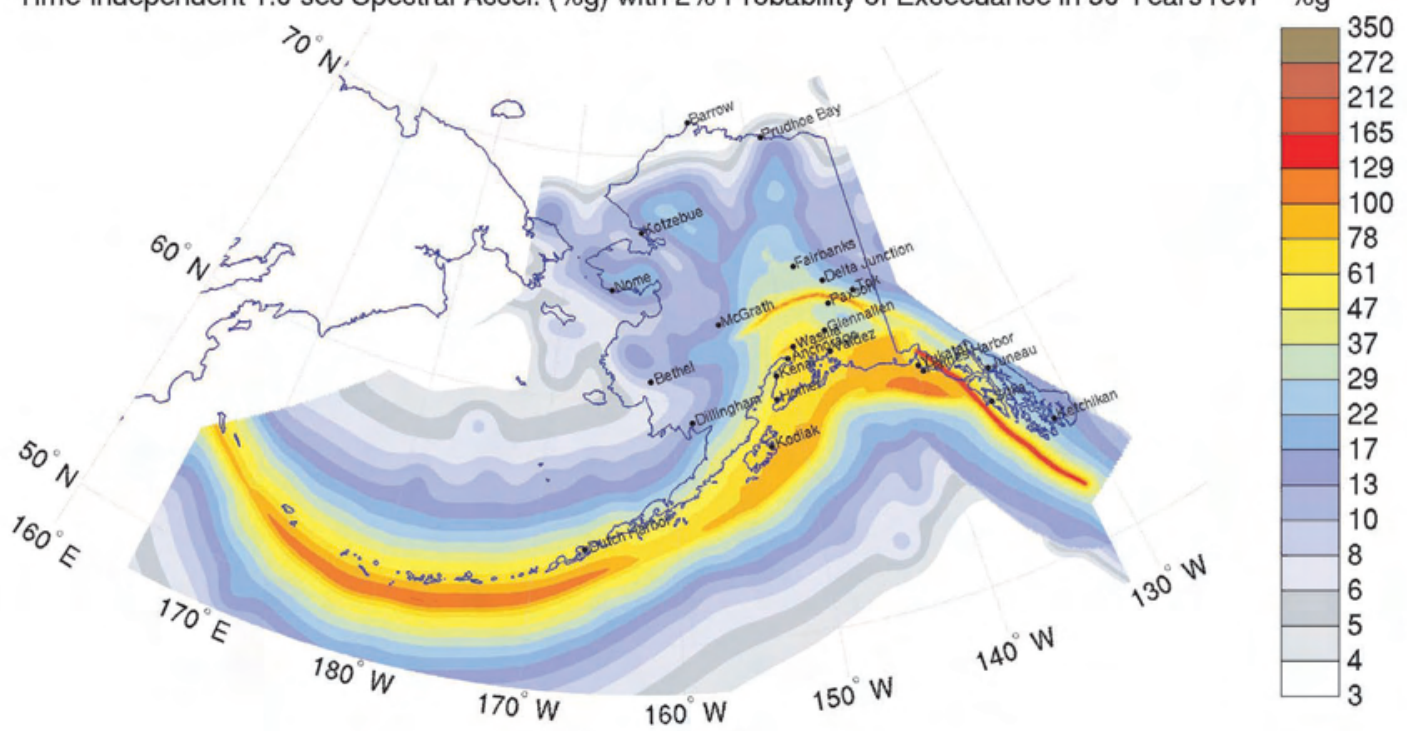

Figure 10. Probabilistic ground motion with a 2-percent probability of exceedance in 50 years for peak ground acceleration $(A), 0.2$ second spectral acceleration $(B), 1.0$ second spectral acceleration $(C)$. 
A. PGA with $10 \%$ probability of exceedance in 50 years
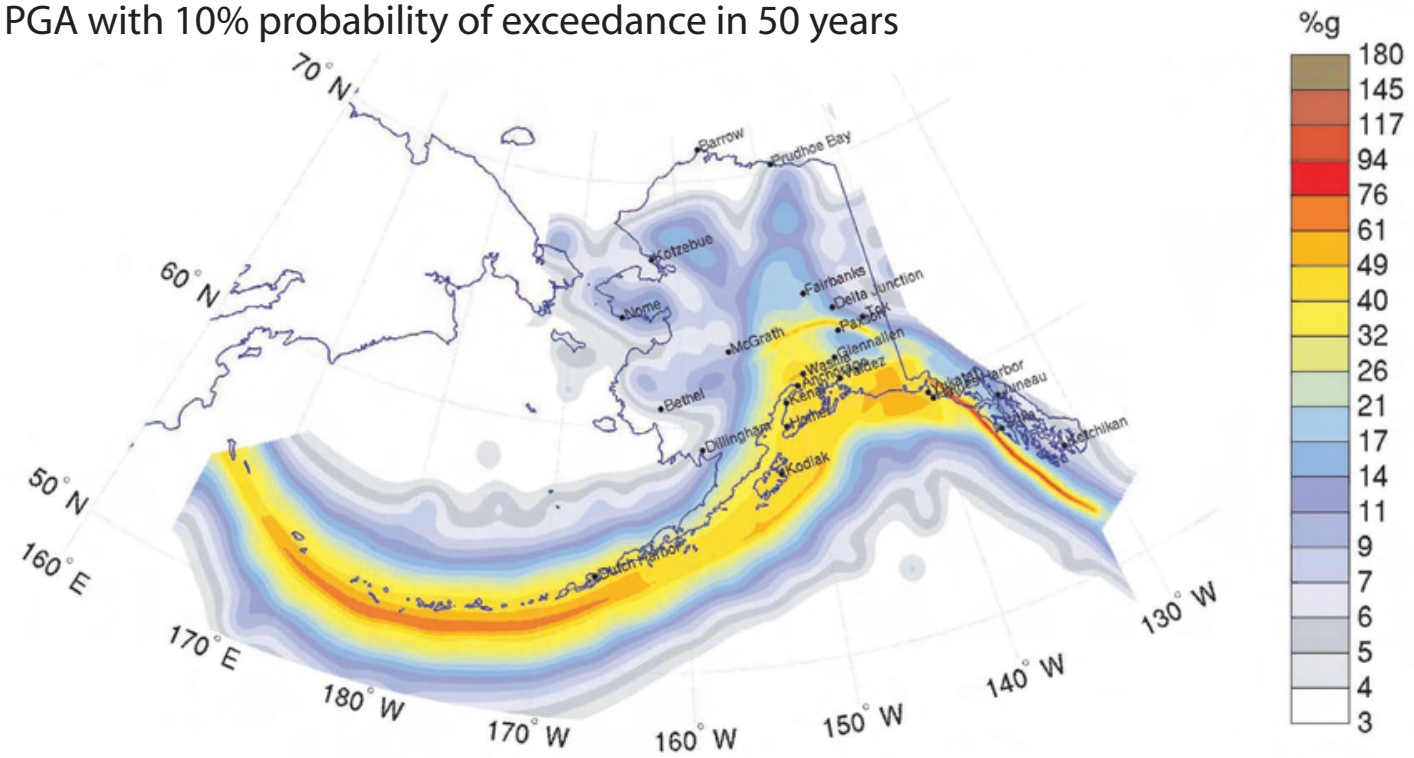

B. 0.2 second SA with $10 \%$ probability of exceedance in 50 years
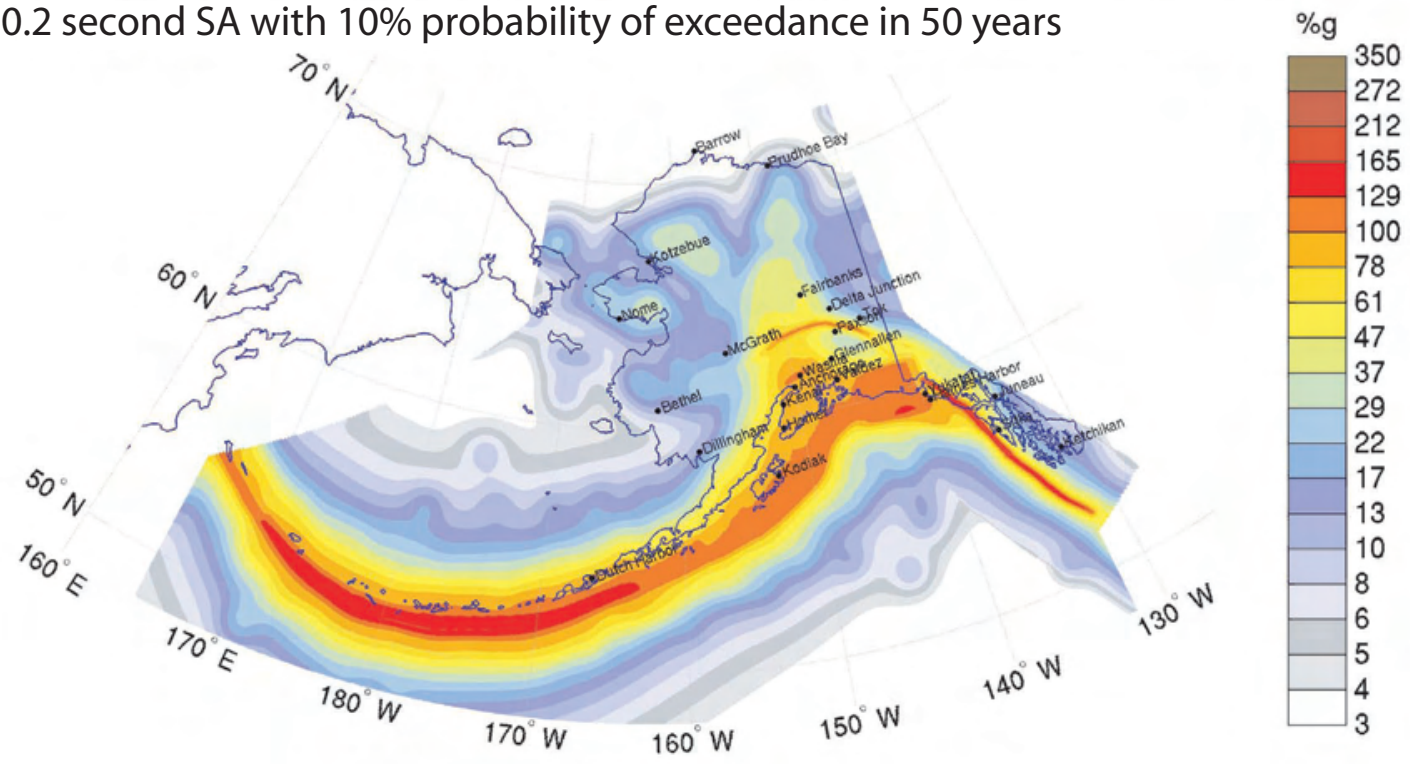

C. 1.0 second SA with $10 \%$ probability of exceedance in 50 years
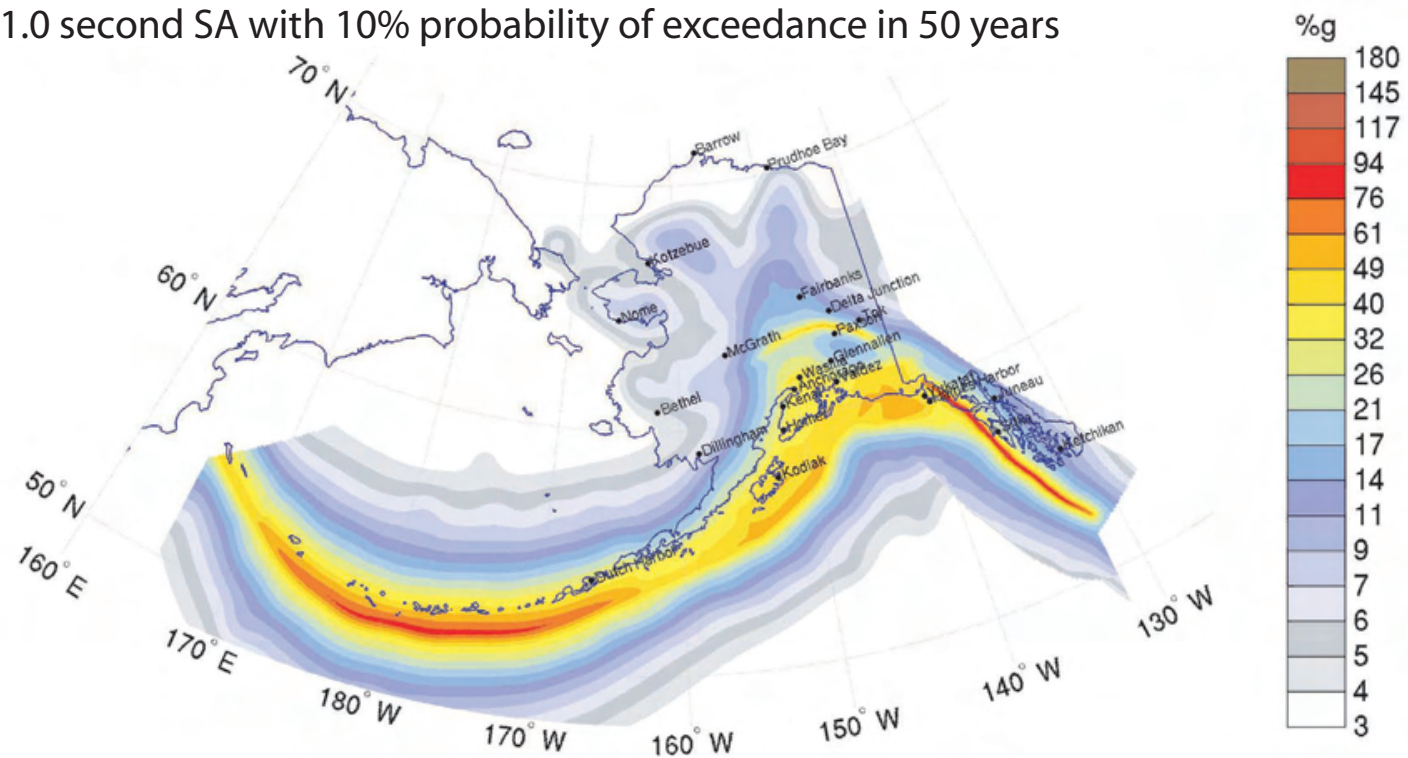

Figure 11. Probabilistic ground motion with a 10-percent probability of exceedance in 50 years for peak ground acceleration $(A), 0.2$ second spectral acceleration $(B)$, and 1.0 second spectral acceleration $(C)$. 
A.
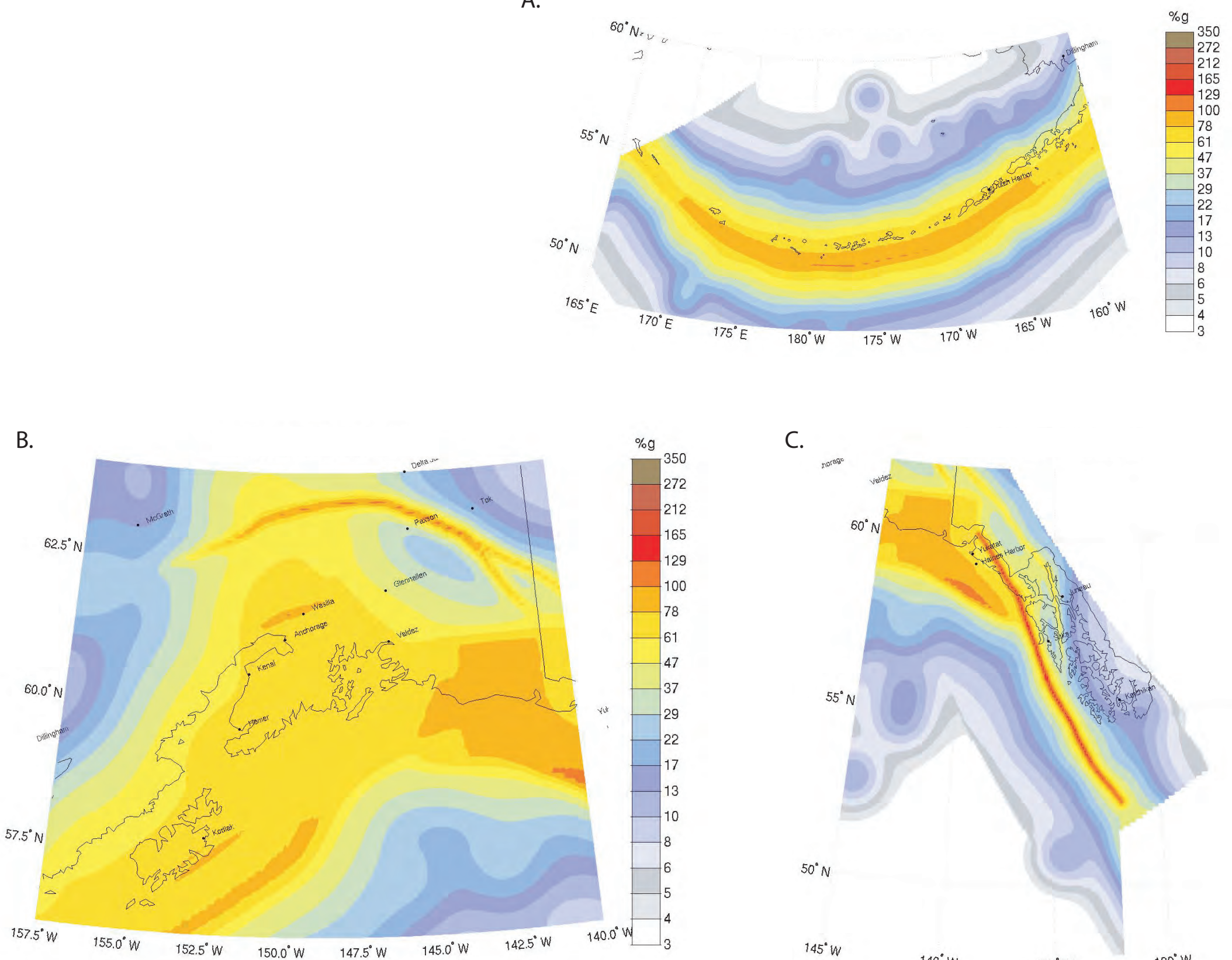

C.
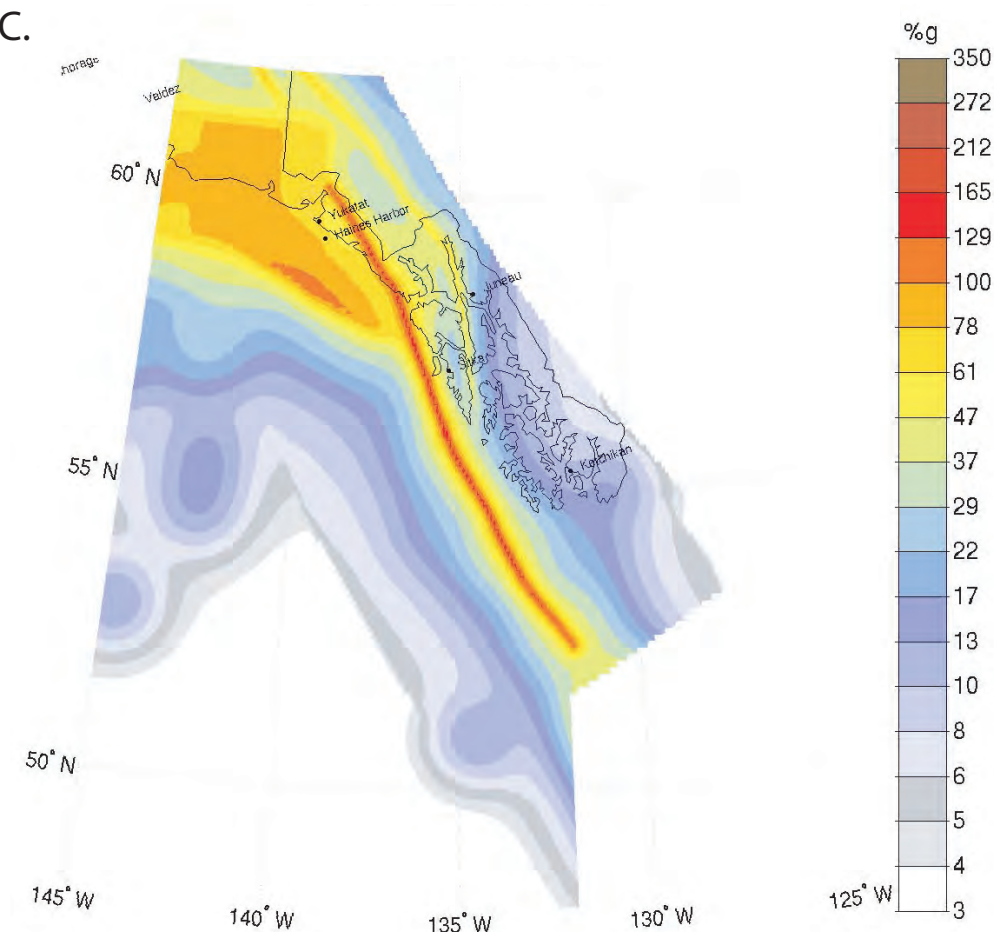

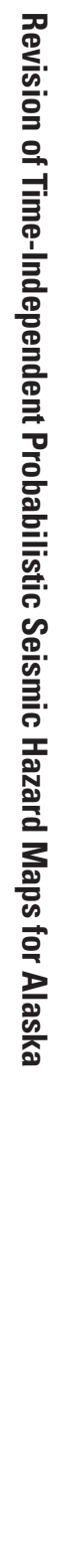

Figure 12. Probabilistic ground motion with a 2-percent probability of exceedance in 50 years for peak ground acceleration at a larger scale in the Aleutians $(A)$, south-central Alaska $(B)$, and south-east Alaska $(C)$. 


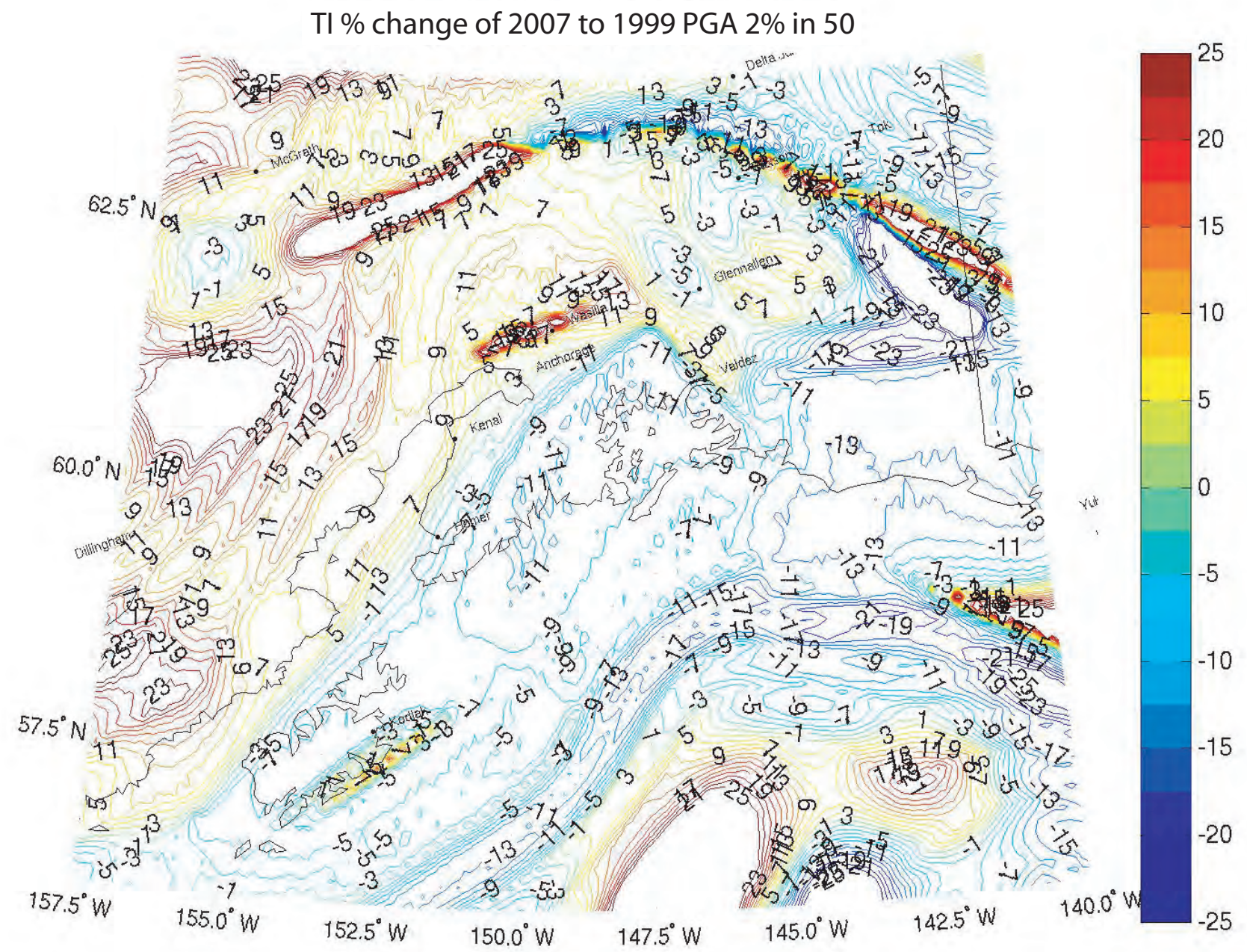

Figure 13. Percentage changes in the 2007 map relative to the 1999 map for south-central Alaska. 


\section{Discussion}

Overall, changes in the characterization of the subduction zone were modest, and although judged to have a more satisfactory justification in terms of observation and understanding, the hazard in the subduction zone was little affected. The largest changes in 2005 map, as contrasted with 1999, are in the vicinity of the Castle Mountain, eastern Denali, and Totschunda faults and the southeastern shore of Kodiak Island. Detailed comparison of the 2005 and 1999 maps for 2 percent in 50 years PGA for south-central Alaska is shown in figure 13. It should be borne in mind that the net difference between the two maps is the result of many changes, mostly small. The changes aggregating to make the net differences in figure 13 include:

- Increased slip rate and decreased recurrence interval on Castle Mountain fault (increases hazard).

- Increased slip rate and decreased recurrence interval on eastern Denali fault (increases hazard).

- Extending the active Denali fault to the west with slip rate tapering to zero (increases hazard).

- Decreased slip rate on Totschunda fault (decreases hazard).
- New attenuation relations (mostly decreases hazardmost visible in Yakataga region, but increases hazard for very shallow faults, for example the Transition fault).

- Addition of Kodiak Island and Narrow Cape faults on and adjacent to Kodiak Island (increases hazard).

- Slightly shallower geometry for megathrust interface under Cook Inlet (increases hazard).

- Slightly lower slip rate for the southern Fairweather and Queen Charlotte faults (reduces the hazard).

- Changes in the rates of earthquakes along the subduction zone (reduces hazard).

Comparison of selected ground-motion values at representative cities and towns in Alaska and the percentage change from the previous version of the map are shown in table 4 .

\section{Conclusions}

We have prepared revised versions of the probabilistic seismic hazard maps for Alaska and the Aleutians. These maps will be proposed for adoption in future revisions to the International Building Code. Digital versions of these maps are available at http://earthquake.usgs.gov/research/hazmaps/. 
Table 4. Selected ground-motion values and percentage changes from the 1999 map at representative cities and towns in Alaska and the Aleutians. [\%, percent; $\mathrm{Hz}$, hertz; pga, peak ground acceleration]

Comparison of 1999 to 2007

2007

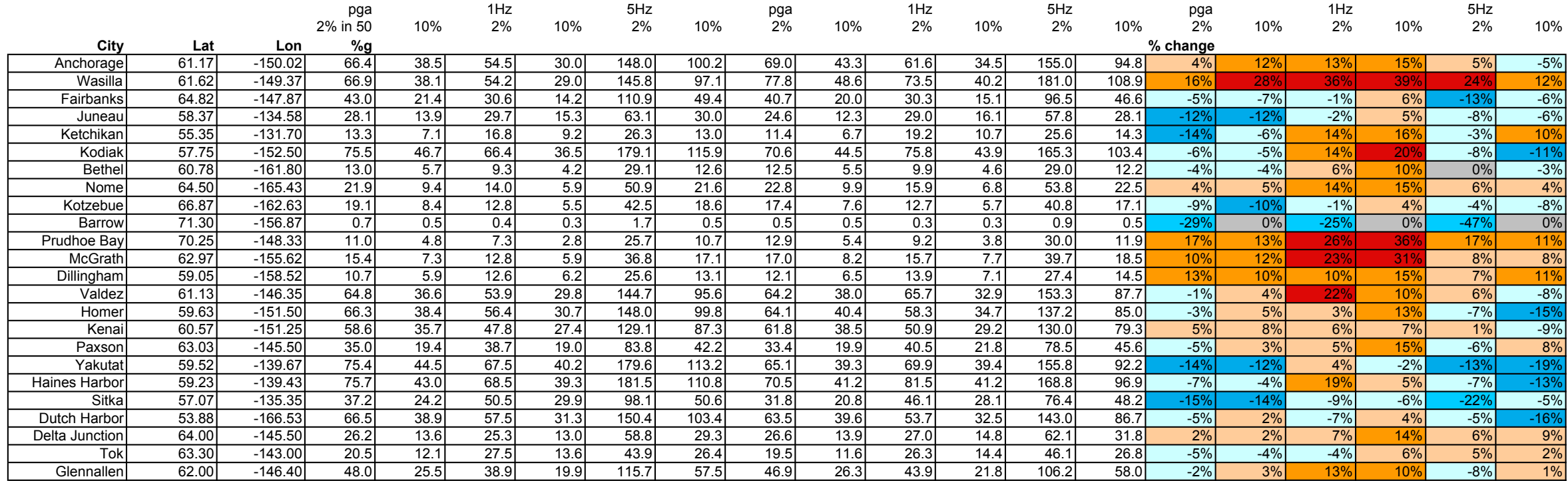




\section{References Cited}

Abrahamson, N.A., and Silva, W.J., 1997, Empirical response spectral attenuation relations for shallow crustal earthquakes: Seismological Research Letters, v. 68, no. 1, p. 94-127.

Atkinson, G.M., and Boore, D.M., 2003, Empirical groundmotion relations for subduction-zone earthquakes and their application to Cascadia and other regions: Bulletin of the Seismological Society of America, v. 93, no. 4, p. 1703-1729.

Bartsch-Winkler, S.B., and Schmoll, H.R., 1992, Utility of radiocarbon-dated stratigraphy in determining late Holocene earthquake recurrence intervals, upper Cook Inlet region, Alaska: Geological Society of America Bulletin, v. 104, no. 6, p. 684-694.

Bemis, S.P., 2004, Neotectonic framework of the north-central Alaska Range foothills: Fairbanks, University of Alaska Fairbanks, 142 p.

Boore, D. M., Joyner, W. and Fumal T., 1997, Equations for estimating horizontal response spectra and peak acceleration from Western North American earthquakes-a summary of recent work: Seismological Research Letters, v. 68, no. 1, p. 128-153.

Boyd, T.M., Engdahl, E.R., and Spence, W., 1995, Seismic cycles along the Aleutian arc-Analysis of seismicity from 1957 through 1991: Journal of Geophysical Research, v. 100 , p. $621-644$.

Bruhn, R.L., 1979, Holocene displacements measured by trenching the Castle Mountain fault near Houston, Alaska, in Short notes on Alaska geology: Alaska Division of Geological and Geophysical Surveys, Geologic Report 61, Anchorage, Alaska, 4 p.

Buergmann, R., Kogan, M.G., Steblov, G.M., Hilley, G., Levin, V.E., and Apel, E., 2005, Interseismic coupling and asperity distribution along the Kamchatka subduction zone: Journal of Geophysical Research, v. 110, B07405, doi:10.1029/2005JB003648.

Bufe, C.G., 2005, Stress distribution along the FairweatherQueen Charlotte transform fault system: Bulletin of the Seismological Society of America, v. 95, no. 5, 2001-2008.

Campbell, K.W., and Bozorgnia, Y., 2003, Updated nearsource ground-motion (attenuation) relations for the horizontal and vertical components of peak ground acceleration and acceleration response spectra: Bulletin of the Seismological Society of America, v. 93, p. 314-331.

Carver, G.A., Lettis, W.R., and Witter, R.C., 2003, Seismic hazard evaluation, Kodiak LORAN Station, Phase I, Phase II and Phase III: Reports prepared for the U.S. Coast Guard, Civil Engineering Unit, Juneau, Alaska.
Cluff, L.S., Page, R.A., Slemmons, D.B., and Crouse, C.B., 2003, Seismic hazard exposure for the Trans-Alaska Pipeline, in Sixth U.S. Conference and Workshop on Lifeline Earthquake Engineering, American Society of Civil Engineers Technical Council on Lifeline Engineering, August 10-13, Long Beach, Calif.

Cohen, S.C., and Freymueller, J.T., 2004, Crustal deformation in the south-central Alaska subduction zone: Advances in Geophysics, v. 47, p. 1-63.

Combellick, R.A., 1994, Investigation of peat stratigraphy in tidal marshes along Cook Inlet, Alaska, to determine the frequency of 1964-style earthquakes in the Anchorage region: State of Alaska, Department of Natural Resources, Division of Geological and Geophysical Surveys.

Cormier, V. F., 1975, Tectonics near the junction of the Aleutian and Kuril-Kamchatka arcs and a mechanism for the middle Tertiary magmatism in the Kamchatka basin: Geological Society of America Bulletin, v. 86, p. 443-453.

Crone, A.J., Personius, S.F., Craw, P.A., Haeussler, P.J., and Staft, L.A., 2004, The Susitna Glacier thrust fault-Characteristics of surface ruptures on the fault that initiated the 2002 Denali Fault earthquake: Bulletin of the Seismological Society of America, v. 94, no. 6, part B, p. 5-22.

Cornell, A., 1968, Engineering seismic risk analysis: Bulletin Seismological Society of America, v. 58, p. 1583-1606.

Davies, J.N., Sykes, L.R., House, L., and Jacob, K., 1981, Shumagin seismic gap, Alaskan peninsula-History of great earthquakes, tectonic setting and evidence for high seismic potential: Journal of Geophysical Research, v. 86, p. 3821-3855.

DeMets, C., and Dixon, T.H., 1999, New kinematic models for Pacific-North America plate motion from 3 Ma to present, I-Evidence for steady motion and biases in the NUVEL1A model: Geophysical Research Letters, v. 26, no. 13, p. 1921-1924.

DeMets, C., Gordon, R., Argus, D., and Stein, S., 1994, Effect of recent revisions to the geomagnetic reversal time scale on estimates of current plate motions: Geophysical Research Letters, v. 21 no. 20, p. 2191-2194.

Detterman, R.L., Plafker, G., Hudson, T., Tysdal, R.G., and Pavoni, N., 1974, Surface geology and Holocene breaks along the Susitna segment of the Castle Mountain fault, Alaska: U.S. Geological Survey MF Map 618, 1 sheet.

Detterman, R.L., Plafker, G., Russell, G.T., and Hudson, T., 1976, Features along part of the Talkeetna segment of the Castle Mountain-Caribou fault system, Alaska: U.S. Geological Survey MF Map 638, 1 sheet.

Doser, D.I., 2004, Seismicity of the Denali-Totschunda fault zone in central Alaska (1912-1988) and its relation to the 
2002 Denali fault earthquake sequence: Bulletin of the Seismological Society of America, v. 94, no. 6, p. S132-S144.

Doser, D.I., Ratchkovski, N.A., Haeussler, P.J., and Saltus, R., 2004, Changes in crustal seismic deformation rates associated with the 1964 great Alaska earthquake: Bulletin of the Seismological Society of America, v. 94, no. 1, p. 320-325.

Doser, D.I., 2006, Relocation of earthquakes (1899-1917) in south-central Alaska: Pure and Applied Geophysics, v. 163, p. 1461-1476.

Eberhart-Phillips, D., Haeussler, P.J., Freymueller, J.T., Frankel, A.D., Rubin, C.M., Craw, P., Ratchkovski, N.A., Anderson, G., Carver, G.A., Crone, A.J., Dawson, T.E., Fletcher, H., Hansen, R., Harp, E.L., Harris, R.A., Hill, D.P., Hreinsdottir, S., Jibson, R.W., Jones, L.M., Kayen, R.E., Keefer, D.K., Larsen, C.F., Moran, S.C., Personius, S.F., Plafker, G., Sherrod, B.L., Sieh, K., Sitar, N., and Wallace, W.K., 2003, The 2002 Denali fault earthquake, Alaska-A large magnitude, slip-partitioned event: Science, v. 300, no. 5622, p. 1113-1118.

Field, E. H., Jackson, D.D. and Dolan, J.F., 1999, A mutually consistent seismic-hazard source model for southern California: Bulletin of the Seismological Society of America, v. 89 , no. $3,559-578$.

Fletcher, H.J., Beavan, J., Freymueller, J., and Gilbert, L., 2001, High interseismic coupling of the Alaska subduction zone SW of Kodiak Island inferred from GPS data: Geophysical Research Letters, v. 28, no. 3, p. 443-446.

Fletcher, H.J., and Christensen, D.H., 1996, A determination of source properties of large intraplate earthquakes in Alaska: Pure and Applied Geophysics, v. 146, no. 1, p. 21-41.

Fletcher, H.J., and Freymueller, J.T., 2003, New constraints on the motion of the Fairweather fault, Alaska, from GPS observations: Geophysical Research Letters, v. 30, no. 3, p. 1139, doi:10.1029/2002GL016476.

Frankel, A. D., 1995, Mapping seismic hazard in the Central and Eastern United States: Seismological Research Letters, v. 66, no. 4 , p. 8-21.

Frankel, A. D., Mueller, C., Barnhard, T., Perkins, D., Leyendecker, E., Dickman, N., Hanson, S., and Hopper, M., 1996, National seismic-hazard maps, Documentation June 1996: U.S. Geological Survey Open-File Report 96-532, 110 pages.

Frankel, A. D., Petersen, M.D., Mueller, C.S., Haller, K.M., Wheeler, R.L., Leyendecker, E.V., Wesson, R.L., Harmsen, S.C., Cramer, C.H., Perkins, D.M., and Rukstales, K.S., 2002, Documentation for the 2002 update of the National Seismic Hazard Maps: U.S. Geological Survey Open-File Report 2002-420.

Freymueller, J.T., and Beavan, J., 1999, Absence of strain accumulation in the western Shumagin Segment of the
Alaska subduction zone: Geophysical Research Letters, v. 26 , no. 21 , p. 3233-3336.

Freymueller, J.T., and Fletcher, H.J., 1999, New GPS constraints on the motion of the Yakutat block: Geophysical Research Letters, v. 26, no. 19, p. 3029-3032.

Gabrielse, H., 1985, Major dextral transcurrent displacements along the northern Rocky Mountain Trench and related lineaments in north-central British Columbia: Geological Society of America Bulletin, v. 96, p. 1-14.

Gardner, J.K., and Knopoff, L., 1974, Is the sequence of earthquakes in southern California, with aftershocks removed, Poissonian?: Bulletin of the Seismological Society of America, v. 64, no. 5, p. 1363-1367.

Geist, E.L., and Scholl, D.W., 1994, Large-scale deformation related to the collision of the Aleutian Arc with Kamchatka: Tectonics, v. 13 , no. 3 , p. 538-560.

Haeussler, P.J., Best, T.C., and Waythomas, C.F., 2002, Paleoseismology at high latitudes; seismic disturbance of upper Quaternary deposits along the Castle Mountain Fault near Houston, Alaska: Geological Society of America Bulletin, v. 114, no. 10, p. 1296-1310.

Haeussler, P.J., Bruhn, R.L., and Pratt, T.L., 2000, Potential seismic hazards and tectonics of the upper Cook Inlet basin, Alaska, based on analysis of Pliocene and younger deformation: Geological Society of America Bulletin, v. 112, no. 9, p. 1414-1429.

Haeussler, P.J., Schwartz, D.P., Dawson, T.E., Stenner, H.D., Lienkaemper, J.J., Sherrod, B., Cinti, F.R., Montone, P., Craw, P.A., Crone, A.J., and Personius, S.F., 2004, Surface rupture and slip distribution of the Denali and Totschunda Faults in the 3 November 2002 M 7.9 earthquake, Alaska: Bulletin of the Seismological Society of America, v. 94, no. 6 , part B, p. 23-52.

Hall, W.J., Nyman, D.J., Johnson, E.R., and Norton, J.D., 2003, Performance of the Trans-Alaska Pipeline in the November 3, 2002 Denali Fault Earthquake, in Sixth U.S. Conference and Workshop on Lifeline Earthquake Engineering: American Society of Civil Engineers Technical Council on Lifeline Engineering, August 10-13, Long Beach, Calif.

Hamilton, S., and Shennan, I., 2005, Late Holocene relative sea-level changes and the earthquake deformation cycle around upper Cook Inlet, Alaska: Quaternary Science Reviews 24, p. 1479.

Hamilton, S., Shennan, I., Combellick, R., Mulholland, J., and Noble, C., 2005, Evidence for two great earthquakes at Anchorage, Alaska and implications for multiple great earthquakes through the Holocene: Quaternary Science Reviews 24, p. 2050. 
Hyndman, R.D., Adams, J., Cassidy, J.F., Rogers, G.C., and Mazzotti, S., 2005, Earthquakes and seismic hazard in the Yukon-Beaufort-Mackenzie: Geological Survey of Canada.

Johnson, J.M., Tanioka, Y., Ruff, L.J., Satake, K., Kanamori, H., and Sykes, L.R., 1994, The 1957 Great Aleutian Earthquake: Pure and Applied Geophysics, v. 142, no. 1, p. 3-28.

Lahr, J., Page, R.A., Stephens, C.D., and Fogelman, K.A., 1986, Sutton, Alaska, earthquake of 1984-Evidence for activity on the Talkeetna segment of the Castle Mountain fault system: Bulletin of the Seismological Society of America, v. 76, p. 967-984.

Lahr, J.C., Stephens, C.D., Hagewara, H.S., and Boatwright, J., 1980, Alaska seismic gap only partially filled by 28 February 1979 earthquake: Science, v. 207, p. 1351-1353.

Lay, Thorne, Kanamori, H., Ammon, C.J., Nettles, M., Ward, S.N., Aster, R.C., Beck, S.L., Bilek, S.L., Brudzinski, M.R., Butler, R., DeShon, H.R., Ekstrom, G., Satake, K., Sipkin, S., and Hanson, B., 2005, The great Sumatra-Andaman earthquake of 26 December 2004: Science, v. 308, no. 5725, p. $1127-1133$.

Matmon, Ari, Schwartz, D.P., Haeussler, P.J., Finkel, R., Lienkaemper, J.J., Stenner, H.D., and others, 2006, Denali fault slip rates and Holocene-late Pleistocene kinematics of central Alaska: Geology (Boulder), v. 34, no. 8, p. 645-648.

Mazzotti, Stephane, Hyndman, R.D., Fluck, P., Smith, A.J., and Schmidt, M., 2003, Distribution of the Pacific/North America motion in the Queen Charlotte Islands-S. Alaska plate boundary zone: Geophysical Research Letters, v. 30, no. 14, p. 1762, doi:10.1029/2003GL017586.

Nishenko, S.P., and Jacob, K.H., 1990, Seismic potential of the Queen Charlotte-Alaska-Aleutian-seismic zone, Journal of Geophysical Research, v. 95, p. 2511-2532.

Pacheco, J., Sykes, L., and Scholz, C., 1993, Nature of seismic coupling along simple plate boundaries of the subduction type: Journal of Geophysical Research, v. 98, p. 14133-14159.

Page, R.A., Biswas, N.N., Lahr, J.C., Pulpan, H., 1991, Seismicity of continental Alaska, In Slemmons, D.B., Engdahl, E.R., Zoback, M.R., and Blackwell, D.D., eds., Neotectonics of North America: Boulder, Colorado, Geological Society of America, Decade Map Volume 1, p. 47-68.

Page, R.A., Plafker, G., and Pulpan, H., 1995, Block rotation in east-central Alaska-A framework for evaluating earthquake potential?: Geology, v. 23, no. 7, p. 629-632.

Pavlis, T.L., Picornell, C., Serpa, L., Bruhn, R.L., and Plafker, G., 2004, Tectonic processes during oblique collisionInsights from the St. Elias orogen, northern North American Cordillera: Tectonics, v. 23, no. 3, TC3001, doi:10.1029/ 2003 TC001557.
Plafker, G.F., Gilpin, L., and Lahr, J., 1993, Neotectonic map of Alaska, in Geology of Alaska: Volume G-1 of Geology of North America, Geological Society of America, Boulder, Colo.

Plafker, G.F., and Rubin, M., 1994, Paleoseismic evidence for "yo-yo" tectonics above the eastern Aleutian subduction zone-Coseismic uplift alternating with even larger interseismic submergence, in Proceedings of the Workshop on Paleoseismology, Prentice, C.S., Schwartz, D.P., and Yeats, R.S., convenors: U.S. Geological Survey Open-File Report 94-568, p. 155-157.

Ratchkovski, N.A., and Hansen, R.A., 2002a, New constraints on tectonics of interior Alaska-Earthquake locations, source mechanisms, and stress regime: Bulletin of the Seismological Society of America, v. 92, no. 3, p. 998-1014.

Ratchkovski, N.A., and Hansen, R.A., 2002b, New evidence for segmentation of the Alaska subduction zone: Bulletin of the Seismological Society of America, v. 92, no. 5, p. 1754-1765.

Ratchkovski, N.A., Wiemer, S., and Hansen, R.A., 2004, Seismotectonics of the central Denali fault, Alaska, and the 2002 Denali fault earthquake sequence: Bulletin of the Seismological Society of America, v. 94, no. 6B, p. S156-174.

Roddick, J.A., 1967, Tintina Trench: Journal of Geology, v. 75, p. 23-33.

Sadigh, K., Chang, C., Egan, J., Makdisi, F., and Youngs, R., 1997, Attenuation relationships for shallow crustal earthquakes based on California strong motion data: Seismological Research Letters, v. 68, no. 1, p. 180-189.

Sauber, J.M., Carver, G., Cohen, S.C., and King, R., in press, Crustal deformation and the seismic cycle across the Kodiak Islands, Alaska: Journal of Geophysical Research.

Sauber, J.M., McClusky, S., and King, R., 1997, Relation of ongoing deformation rates to the subduction zone process in southern Alaska: Geophysical Research Letters, v. 24, no. 22, p. 2853-2856.

Sauber, J.M., McClusky, S., and King, R., 1998, Relation of ongoing deformation rates to the subduction zone process in southern Alaska, correction: Geophysical Research Letters, v. 25 , no. 2 , p. $215-215$.

Sauber, J.M., and Molnia, B.F., 2004, Glacier ice mass fluctuations and fault instability in tectonically active southern Alaska: Global and Planetary Change, v. 42, no. 1-4, p. 279-293.

Schwartz, D. P., Haeussler, P.J., Matmon, A., Dawson, T.E., Seitz, G., Stenner, H., and others, 2005a, Earthquake geology of the Denali fault system, Alaska-Proceedings of the 5th U.S.-Japan Natural Resources Meeting and Parkfield, California fieldtrip: U.S. Geological Survey Open-File Report No. OF 2005-1131, p. 25-29. 
Schwartz, D.P., Haeussler, P.J., Seitz, G.G., Dawson, T.E., Stenner, H.D., and others, 2005b, Unraveling the earthquake history of the Denali fault system, Alaska-Filling a blank canvas with paleoearthquakes: Eos Transactions of the American Geophysical Union, v. 86, no. 52, Fall Meeting Supplement, Abstract U42A-06.

Sella, G.F., Dixon, T.H., and Mao, A., 2002, REVEL-A model for recent plate velocities from space geodesy: Journal of Geophysical Research, v. 107, no. B4, doi:10.1029/ 2000JB000033.

Shennan, Ian, and Hamilton, S., 2006, Coseismic and pre-seismic subsidence associated with great earthquakes in Alaska: Quaternary Science Reviews, v. 25, p. 1-8.

Sipkin, S.A., 2003, A correction to body-wave magnitude mb based on moment magnitude Mw: Seismological Research Letters, v. 74, p. 739-742.

Smith, A.J., Hyndman, R.D., Cassidy, J.F., and Wang, K., 2003, Structure, seismicity, and thermal regime of the Queen Charlotte Transform Margin: Journal of Geophysical Research-Solid Earth, v. 108, no. B11, p. 2539, doi:10.1029/ 2002JB002247.

Sykes, L.R., 1971, Aftershock zones of great earthquakes, seismicity gaps, and earthquake prediction for Alaska and the Aleutians: Journal of Geophysical Research, v. 76, p. 8021-8041.

Sykes, L.R., Kisslinger, J.B., House, L., Davies, J.N., and Jacob, K.H., 1981, Rupture zones and repeat times of great earthquakes along the Alaska-Aleutian arc, in Simpson D.W., and Richards, P.G., eds., Earthquake prediction: American Geophysical Union, p. 73-80.

Taber, J.J., Billington, S., and Engdahl, E.R., 1991, Seismicity of the Aleutian arc, in Slemmons, D.B., Engdahl, E.R., Zoback, M.R., and Blackwell, D.D., eds., Neotectonics of North America: Boulder, Colorado, Geological Society of America, Decade Map Volume 1, p. 29-46.
Thenhaus, P.C., Ziony, J.I., Diment, W.H., Hopper, M.G., Perkins, D.M., Hanson, S.L., and Algermissen, S.T., 1985, Probabilistic estimates of maximum seismic horizontal ground acceleration on rock in Alaska and the adjacent continental shelf: Earthquake Spectra, v. 1, p. 285-306.

Utsu, T., 2002, Relationships between magnitude scales, in Lee, W.H.K, Kanamori, H., Jennings, P.C., and Kisslinger, C., editors, International Handbook of Earthquake and Engineering Seismology: Academic Press, a division of Elsevier, two volumes, International Geophysics, v. 81-A, p. 733-746.

Weichert, D.H., 1980, Estimation of earthquake recurrence parameters for unequal observation periods for different magnitudes: Bulletin of the Seismological Society of America, v. 70, p. 1337-1356.

Wells, D.L., and Coppersmith, K.J., 1994, New empirical relationships among magnitude, rupture length, rupture width, rupture area, and surface displacement: Bulletin of the Seismological Society of America, v. 84, no. 4, p. 974-1002.

Wesson, R.L., Frankel, A.D., Mueller, C.S., and Harmsen, S., 1999a, Probabilistic seismic hazard maps of Alaska: U.S. Geological Survey Open-File Report 99-36.

Wesson, R.L., Frankel, A.D., Mueller, C.S., and Harmsen, S., 1999b, Probabilistic seismic hazard maps of Alaska: U.S. Geological Survey Miscellaneous Investigations Series I-2679.

Willis, J.B., Haeussler, P.J., Bruhn, R.L., and Willis, G.C., in press, Holocene slip rate and revised characteristic earthquake parameters for the western segment of the Castle Mountain fault, Alaska: Bulletin of the Seismological Society of America.

Youngs, Robert, Chiou, S., Silva, W., and Humphrey, J., 1997, Strong ground-motion attenuation relationships for subduction zone earthquakes: Seismological Research Letters, v. 68 , no. 1, p. $58-73$. 